\title{
CROWDFUNDING: A REVIEW AND RESEARCH AGENDA
}

\author{
Inés Alegre
}

Melina Moleskis 


\title{
CROWDFUNDING: A REVIEW AND RESEARCH AGENDA
}

\author{
Inés Alegre ${ }^{1}$ \\ Melina Moleskis²
}

\begin{abstract}
Crowdfunding is an alternative model for project financing, whereby a large and dispersed audience participates through relatively small financial contributions, in exchange for physical, financial or social rewards. It is usually done via Internet-based platforms that act as a bridge between the crowd and the projects. Over the past few years, academics have explored this topic, both empirically and theoretically. However, the mixed findings and array of theories used have come to warrant a critical review of past works. To this end, we perform a systematic review of the literature on crowdfunding and seek to extract (1) the key management theories that have been applied in the context of crowdfunding and how these have been extended, and (2) the principal factors contributing to success for the different crowdfunding models, where success entails both fundraising and timely repayment. In the process, we offer a comprehensive definition of crowdfunding and identify avenues for future research based on the gaps and conflicting results in the literature.
\end{abstract}

Keywords: Crowdfunding; Literature review; Success factors

\footnotetext{
${ }^{1}$ Professor, Managerial Decision Sciences, IESE

${ }^{2} \mathrm{PhD}$ candidate, IESE
} 


\section{CROWDFUNDING: A REVIEW AND RESEARCH AGENDA}

\section{Introduction}

Wolfgang Amadeus Mozart, in the early days of his career, lacked sufficient sponsorship to fund his concerts and had to turn to crowdfunding to raise money to organize three events at a Viennese concert hall. Mozart rewarded his sponsors by offering them manuscripts of the concertos (Schroter, 2014). At that time, long before the Internet, it took the musical genius more than two years to raise the necessary financing. Today, with the power of the Internet, the crowd can provide the money in just a few minutes.

Crowdfunding has its roots in the broader concept of crowdsourcing, which enlists the services of the crowd to obtain feedback, new ideas and solutions, aimed at promoting business activities (Lambert and Schwienbacher, 2010). Only, in the case of crowdfunding, the goal is to attract the financial resources necessary for a particular project. But crowdfunding differs from traditional seed finance because it involves small investments from less sophisticated investors, whose motives range from financing entrepreneurial ventures to donating to charitable causes, and inherently a high degree of uncertainty and information asymmetry accompany the virtual nature of the interaction medium. These characteristics of crowdfunding distinguish it from traditional channels of business financing, such as bank loans and venture capital, that have been explored thoroughly in the management literature. By contrast, crowdfunding is a new phenomenon that does not fall into the category of traditional finance and, consequently, it has attracted the attention of many scholars over the past few years. Such scholars first endeavored to define the concept (e.g., Lambert and Schwienbacher, 2010; Mollick, 2014), then explored various factors affecting success rates (e.g., Agrawal et al., 2015; Moss et al., 2014; Zheng et al., 2014), and sought to understand the theoretical mechanisms behind the process and the actions of the participants (e.g., Belleflamme et al., 2013; Burtch et al., 2014; Cholakova and Clarysse, 2015). In the process, scholars from different fields have applied an array of management theories in the context of crowdfunding.

Interestingly, academic research on the topic so far has been mainly exploratory and remarkably diverse in terms of field of study and theoretical approach. Though exploration and diversity are natural features of the literature on a nascent topic, in order for scientific knowledge to advance in well thought-out directions, a critical synthesis of findings to date is deemed beneficial. For this reason, academic literature on crowdfunding warrants a systematic literature review to 
uncover the evidence behind crowdfunding's success factors and the theoretical mechanisms in play. In this paper, we undertake this task and systematically identify, collect, analyze and synthesize the 82 papers that form the universe of peer-reviewed academic literature on crowdfunding to date.

Like other innovations in entrepreneurial finance, crowdfunding emerged both as a consequence of improvements in technology and as a result of imbalances between the supply of and demand for capital, exacerbated by the economic shocks of the early 21st century (Bruton et al., 2015). Though the practice of raising funds from the crowd has existed for centuries in its offline form, it was the proliferation of Web 2.0 technologies and the birth of online social platforms acting as two-sided markets that transformed crowdfunding into a widespread and meaningful method of raising alternative finance. In its online form, crowdfunding takes place via social network sites, such as Facebook Causes and Twitter, and specialized crowdfunding platforms such as Kiva and Kickstarter. The commercialization of the Internet meant lower costs to search for funders to match creators, lower risk exposure for funders as funding in small amounts became economically feasible through online transactions, and lower communication costs for distant funders in terms of gathering information and monitoring the progress of the project (Agrawal et al., 2014).

It is worth noting that crowdfunding first appeared in the arts and entertainment industries, such as film production, music and video games. At first there was Sellaband, a music-only platform founded in 2006 and based in Amsterdam. Later came Kickstarter, a broader creative-projects platform founded in 2009 and based in New York (Agrawal et al., 2014). Since then, crowdfunding platforms have appeared across the globe, with many platforms being created in Europe and North America (Dushnitsky et al., 2016). In its few years of existence as an online activity, the concept has gained traction in both not-for-profit and for-profit environments, justifying the attention of numerous scholars. The crowdfunding industry has been on an exponential growth path since 2011 following consecutive annual increases (Dushnitsky et al., 2016), amassing \$34.4 billion in 2015, and is expected to surpass venture capital in 2016 (Massolution, 2015). In 2014, there were 1,250 platforms active worldwide, of which 48\% were located in Europe and 30\% in North America (Massolution, 2015). Nonetheless, North American platforms facilitated about three times more volume than their European counterparts, with North America accounting for $\$ 9.46$ billion and Europe accounting for $\$ 3.26$ billion. In Europe, the United Kingdom was in the lead with $€ 2.3$ billion collected in 2014, which represented 79\% of the total amount collected in the continent. It was followed by France with $€ 154$ million raised, Germany with $€ 140$ million and Sweden with $€ 107$ million (Wardrop et al., 2015).

There are numerous reasons behind the impressive rise in crowdfunding. As an alternative method of raising finance, crowdfunding provides entrepreneurs with lower capital costs (Agrawal et al., 2014), public attention (Belleflamme et al., 2014), presales, and valuable information in the form of early market research and the engagement of potential users in the development of ideas and design of a product (Gerber et al., 2012; Agrawal et al., 2014; Kuti and Madarász, 2014). This engagement of potential users can give legitimacy to the venture and help secure more capital from other sources in subsequent stages (Gerber et al., 2012). At the same time, however, entrepreneurs are required to publicly disclose information about their products and ideas, thereby risking visible failure or giving the impression they are desperate (Gleasure, 2015). In addition, there is an opportunity cost of raising capital from the crowd rather than professional investors in terms of industry knowledge, relationships and status. What is more, there are challenges to managing numerous and diverse investors (Agrawal et al., 2014). 
For the crowd, crowdfunding offers benefits such as easier access to investment opportunities and the opportunity to engage in innovative behavior (Ordanini et al., 2011), early access to new products, a community feeling, pride (Boons et al., 2015), philanthropy, and the formalization of a friend-and-family type of investment (Agrawal et al., 2014). Depending on the type of crowdfunding model, in exchange for their contributions, the members of the crowd may receive some form of physical reward as a token of appreciation, a share of equity and voting rights, interest on loans, or the warm glow of satisfaction that comes from giving a donation. On the negative side, funders face three primary disincentives - namely, entrepreneur incompetence, fraud, and project risk (Agrawal et al., 2014).

With respect to crowdfunding platforms, their growing presence is justified by the existence of up to three revenue sources. First, platforms can earn interest on the money collected from funders for the time period between the money being pledged and it being transferred to the fundraisers (or back to the funders). Second, platforms generate revenue from additional services such as handling payments. Third, they collect transaction fees from successful fundraisers on a percentage basis (Belleflamme et al., 2015). Moreover, a platform's design is based on the type of reward the crowd receives. There are four main business models - namely, donation-based crowdfunding, reward-based crowdfunding, "crowdlending" and "crowdequity" (Kshetri, 2015). In reality, however, in addition to these four categories, there are mixed models of crowdfunding platforms. For instance, Micro Inversores is a mixed-model platform that was launched in Spain at the beginning of 2013 to help individuals and start-ups funding innovative entrepreneurial initiatives. This platform allows campaign participants to use rewards, interest payments and shares simultaneously as compensation for the crowd (Dushnitsky et al., 2016).

Notwithstanding the presence of risks and information asymmetry, crowdfunding is on a path to a bright future. However, raising funds via the crowd is not as easy as it might sound. Success rates vary greatly, depending on the platform. For example, on Kickstarter, for every single successful campaign, two others fail and, in the case of Indiegogo, only one in 10 campaigns is successful (Holm, 2016). In light of the complicated nature of this emerging phenomenon, we undertake a systematic review of the literature on crowdfunding and report their conclusions. In particular, we seek to identify (1) the key management theories that have been applied in the context of crowdfunding and how these have been reinforced or extended, and (2) the principal factors contributing to the campaign success of the various crowdfunding models.

Systematic literature reviews originated with the medical sciences (Tranfield et al., 2003) and "have become fundamental to evidence-based practice and represent a key methodology for locating, appraising, synthesizing, and reporting 'best evidence”" (Briner et al., 2009). We consider that, for a topic that is as interdisciplinary as crowdfunding, that involves mixed evidence regarding the factors leading to its success and that has been the target of many theoretical fields, a systematic literature review can serve to synthesize existing findings, contemplate the application of different theoretical perspectives on this emerging phenomenon, and identify paths for future research. We follow the guidelines established in the management literature: upon selecting the papers to be included in the review in a systematic and transparent way, we explore these papers and identify key themes, using both qualitative and quantitative techniques. Then we focus on the prevailing themes and proceed to trace and investigate them, while identifying gaps and potential avenues for future research (Jones and Gatrell, 2014).

In the next section, we present our step-by-step methodology and provide key descriptive data on all the papers included in this review. In particular, we discuss the journals in which these papers are published, the chronology of publication, the academic fields to which these studies 
belong, and the types of crowdfunding models on which they focus. After this description, we start our analysis by reviewing the different definitions and terminologies proposed for the concept of crowdfunding, identify the key elements of these definitions and offer our own comprehensive definition of the concept. At this point, having already demonstrated the interdisciplinary nature of the topic, we categorize the literature along the dimensions of theoretical perspectives and empirical findings, according to the two research questions guiding this review. The first question is of great interest to academics and involves the array of economic, sociological and psychological theories that have been applied in the context of crowdfunding. The second question is practical in nature and oriented to the key factors contributing to crowdfunding success. Our systematic analysis and synthesis give us unique insights into the gaps in the crowdfunding research literature and highlight the contradictory findings in past studies, which are a prolific source of material for future studies as we discuss in the penultimate section of this paper. We end our study with our main conclusions.

\section{Methodology}

To be useful, a review must have a clear purpose and a specified audience (Rousseau et al., 2008). For this reason, we formulated our research question early on, after a preliminary review of part of the literature but before an in-depth analysis of the papers. The research question then is twofold: (1) What are the key management theories that have been applied in the context of crowdfunding, and how have they been reinforced and extended? And (2) What are the key factors that contribute to the success of crowdfunding in terms of managing both to raise funds and ensure timely repayment?

In order to gather the appropriate array of relevant studies that address the research question, we searched for all crowdfunding literature with no a priori expectations. To locate studies, we did a comprehensive search of the EBSCO Business Source Complete, Science Direct and Web of Knowledge databases. These databases cover all relevant journals in the fields of business, management, finance and economics and therefore will contain all relevant papers on the topic of interest. The search was carried out on February 25, 2016. The primary search strings used were "crowdfunding" and "crowd funding," to be found in the title, abstract or keywords. This search returned 388 papers.

We then used certain inclusion criteria to evaluate the quality of the papers identified, based on the ranking of the publication. In particular, we restricted the search to peer-reviewed academic and practitioner literature, published in top academic journals, in the English language. We found practitioner literature to be relevant (e.g., Harvard Business Review and California Management Review) because of the emerging nature of the crowdfunding phenomenon. We looked at journal rankings in the ISI Web of Knowledge Journal Citation Reports based on the average five-year impact factors and included journals that were ranked in the first and second quartiles in the fields of management, business, social issues, economics and finance. The diversity of fields is emblematic of the interdisciplinary nature of the topic under review. Exclusion of any of the above fields would have deprived our review of vital information. Furthermore, we assessed the relevance of the papers' content with respect to our research questions. This filtering process returned 42 papers. Moreover, we expanded our search to include the terms "crowdsourcing," "microlending," "pro-social lending" and "microfinance." Again, using the aforementioned inclusion and relevance criteria, we were able to sift through these articles, which resulted in the inclusion of five more papers. 
However, even with the systematic review and inclusion criteria, the intention was to be as inclusive as possible to avoid eliminating potentially valuable contributions from unpublished works. Given the embryonic stage of the phenomenon under study, we thought it likely that some papers had not made it through the publication process yet. To this end, we looked at the grey literature on the topic from Google Scholar and the Social Science Research Network. Using the search term "crowdfunding," we identified some papers that dealt with the topic in a scientific manner and decided to include them. Among these were several key references that appeared frequently in many of the selected papers. Despite not having made it into highly ranked journals, these papers were the seeds from which academic interest in crowdfunding flourished, written by renowned experts in the field and therefore any review of the topic would be incomplete without them. Hence, we included 35 more articles in our list. The final result was the 82 papers that comprise the basis of our study, 46 of which appeared in top-ranking journals.

The 43 journals in which these papers were published are listed in Table 1, ranked in descending order according to their average five-year impact factor. The long list of journals bears witness to the diversity of academic fields that have got involved with the topic of crowdfunding. Table 2 offers a chronology of this interest per academic field. Perhaps unsurprisingly, there is virtually no literature on crowdfunding prior to 2010, which is when the seminal paper of Lambert and Schwienbacher came out in the form of a working paper. The paper was published three years later in Venture Capital, with Paul Belleflamme as the main author. Overall, the earliest publication was in 2009, in an article in the Wall Street Journal, which is when the hype started gathering around crowdfunding. The next three years saw a few more publications, most of which were in the form of working papers. The topic gained further traction in 2013, when six papers made their way into top publications. The number rose to nine in the following year and 16 in 2015. In the first two months of 2016, eight more publications were released. The activity has followed a similar growth pattern in journals of lower ranking. Across academic fields, management/business ranks highest among all fields and is where managerial theories are extended and applied to the context of crowdfunding. Next, the fields of economics and finance have a rich portfolio of crowdfunding papers, with a focus on information asymmetry and market mechanisms. Underpinning the importance of crowdfunding for start-ups, the field of entrepreneurship follows closely with a special issue of the journal Entrepreneurship Theory and Practice in 2015. At the bottom of the ladder, other fields where there has been work on crowdfunding are information systems, marketing and nonprofit. Information systems researchers have found crowdfunding suitable for study when it is regarded as a form of fundraising through the Internet. Marketing scholars have been interested in issues such as the marketing of projects and the design of product lines. The not-for-profit sector has shown interest in the donation-based model of crowdfunding. Finally, practitioner magazines have shown ongoing interest from the beginning, an interest that peaked in early 2016 with a special issue on crowdfunding in the California Management Review. 


\section{Tabla 1}

List of journals

\begin{tabular}{|c|c|c|}
\hline Journals & $\begin{array}{c}\text { Number of } \\
\text { publications }\end{array}$ & $\begin{array}{l}\text { Five-year impact } \\
\text { factor }\end{array}$ \\
\hline MIS Quarterly & 1 & 8.490 \\
\hline Organization Science & 1 & 6.309 \\
\hline Journal of International Business Studies & 1 & 6.067 \\
\hline Journal of Management Studies & 1 & 5.883 \\
\hline Academy of Management Perspectives & 1 & 5.427 \\
\hline Journal of Business Venturing & 3 & 5.305 \\
\hline Entrepreneurship Theory and Practice & 6 & 5.073 \\
\hline Journal of Marketing Research & 1 & 3.771 \\
\hline Information Systems Research & 1 & 3.756 \\
\hline Economic Journal & 1 & 3.488 \\
\hline Management Science & 3 & 3.399 \\
\hline Journal of Strategic Information Systems & 1 & 3.388 \\
\hline Journal of Human Resources & 1 & 3.222 \\
\hline Information \& Management & 1 & 3.105 \\
\hline Marketing Science & 1 & 3.035 \\
\hline Journal of Service Management & 1 & 2.882 \\
\hline Journal of Public Economics & 1 & 2.809 \\
\hline Journal of Development Economics & 1 & 2.792 \\
\hline California Management Review & 6 & 2.636 \\
\hline Journal of International Management & 1 & 2.566 \\
\hline Business Horizons & 2 & 2.450 \\
\hline Marketing Theory & 1 & 2.378 \\
\hline Journal of Business Research & 1 & 2.324 \\
\hline Nonprofit and Voluntary Sector Quarterly & 1 & 2.300 \\
\hline Entrepreneurship and Regional Development & 1 & 2.200 \\
\hline Harvard Business Review & 1 & 2.087 \\
\hline Management Decision & 1 & 1.665 \\
\hline Annual Review of Financial Economics & 1 & 1.602 \\
\hline Journal of Economic Behavior \& Organization & 1 & 1.546 \\
\hline Voluntas & 1 & 1.302 \\
\hline Journal of Development Studies & 1 & 1.286 \\
\hline Information Economics and Policy & 1 & 1.129 \\
\hline Research-Technology Management & 1 & 0.966 \\
\hline Journal of Economic Issues & 1 & 0.569 \\
\hline Venture Capital & 4 & \\
\hline Academy of Entrepreneurship Journal & 1 & \\
\hline Book & 1 & \\
\hline Entrepreneurship Research Journal & 1 & \\
\hline Innovation Policy and the Economy & 1 & \\
\hline Journal of Economics and Management & 1 & \\
\hline Public Finance Quarterly & 1 & \\
\hline Strategic Change & 4 & \\
\hline Strategic Finance & 2 & \\
\hline Wall Street Journal & 1 & \\
\hline Working papers & 16 & \\
\hline
\end{tabular}




\section{Tabla 2}

Number of papers per academic field and year of publication

\begin{tabular}{|l|c|c|c|c|c|c|c|c|c|}
\hline & $\mathbf{2 0 0 9}$ & $\mathbf{2 0 1 0}$ & $\mathbf{2 0 1 1}$ & $\mathbf{2 0 1 2}$ & $\mathbf{2 0 1 3}$ & $\mathbf{2 0 1 4}$ & $\mathbf{2 0 1 5}$ & $\mathbf{2 0 1 6}$ Feb & Total \\
\hline Economics/finance & & & 2 & 1 & 2 & 8 & 8 & & 20 \\
\hline Entrepreneurship & & & 1 & 1 & 2 & 4 & 8 & & 15 \\
\hline Information systems & & & & & 1 & 1 & 1 & & 3 \\
\hline Management/business & & 1 & 4 & 4 & 2 & 8 & 6 & 2 & 30 \\
\hline Marketing & & & 1 & & 1 & & 1 & & 3 \\
\hline Not-for-profit/social & & & & 1 & & 1 & 1 & & 2 \\
\hline Practitioner magazines & 1 & & & 1 & 1 & & & 6 & 9 \\
\hline Total & 1 & 1 & 8 & 8 & 9 & 22 & 25 & 8 & 82 \\
\hline
\end{tabular}

A handful of authors are the pioneers in unveiling the topic to the academic world. The team around Schwienbacher is among the first to address entrepreneurial crowdfunding scientifically in Europe (Lambert and Schwienbacher, 2010; Larralde and Schwienbacher, 2012; Belleflamme, Lambert and Schwienbacher, 2013; Belleflamme, Lambert and Schwienbacher, 2014). This includes Lambert, Larralde and Belleflamme. Similarly, Agrawal, Catalini and Goldfarb have investigated the economic aspects of crowdfunding in several studies and produced two top-ranking papers in 2015 and 2016. Furthermore, Allison, Davis and Short comprise another team of authors that appear often in top-ranked journals of entrepreneurship. Lehner has also conducted several studies from the perspective of seed financing for social ventures (Lehner, 2013; Lehner, 2014; Lehner and Nicholls, 2014), while Bruton and Khavul featured in the 2015 Entrepreneurship Theory and Practice special issue. Ethan R. Mollick has also sought to explore the dynamics of crowdfunding from an entrepreneurial perspective (Mollick, 2014; Mollick and Robb, 2016), as have Gerrit K.C. Ahlers and Douglas J. Cumming (Ahlers et al., 2015; Cumming et al., 2015). Moreover, Gordon Burtch has contributed to research on the topic from an information systems perspective (Burtch, Ghose and Wattal, 2014; Burtch, Ghose and Wattal, 2015), while Andrea Ordanini has had an impact from the field of marketing (Ordanini et al., 2011). From a general management perspective, important contributors include Kshetri (2015) and Dushnitsky et al. (2016).

Of the 82 papers included in this systematic literature review, 22 are rated as conceptual and 60 are the results of empirical research. Of those 60 papers, 15 are qualitative (based on case studies and/or interviews), while 45 studies employ online, survey and/or experimental data, followed by statistical analysis. Most of the qualitative studies rely on multiple cases, with only three of them based on a single case. Of the quantitative empirical papers, a mere five studies use survey data and just three are based on experiments - the rest of the studies use vast amounts of online data from major crowdfunding sites such as Kiva, Kickstarter and Prosper. Overall, the geographical dispersion of the data sources is moderate. The United States has the most, since 18 of the studies deal exclusively with U.S. data. Of the rest, eight studies focus on Europe, either by looking at individual countries such as the Netherlands and the United Kingdom or by adopting an aggregate perspective. Other geographical regions considered are Latin America, China, India, Australia and Jordan.

The project is the preferred unit of analysis and study design is cross-sectional in nature, with the exception of Kuppuswamy and Bayus (2015), who use two years of panel data. Symmetrical methods such as ordinary least squares and logistic regressions are the main weapons of choice 
for the majority of quantitative studies, after correcting for variables such as industry, year and location with fixed effects specifications. Notably, one study uses gravity equations with a Poisson pseudomaximum likelihood estimator (Burtch et al., 2014), two others employ differencein-difference analysis (Leung and Sharkey, 2014; Hildebrand et al., 2014), and one researcher has chosen structural equation modeling (Boons et al., 2015). Moreover, the study by Xu et al. (2016) uses qualitative comparative analysis, an asymmetrical set-membership analytical technique appropriate for complex configuration analysis.

It is also interesting to reflect on the type of crowdfunding model these 82 papers have concentrated on (Table 3). Almost half of the papers tackle all crowdfunding models at once without differentiating between them, and this proportion has been more or less constant across time (Table 4). Moreover, these studies are divided equally between conceptual and empirical works, albeit qualitative methodologies dominate over quantitative. Conceptual and qualitative efforts to concentrate on a single crowdfunding model have been sporadic. To date, lending and reward-based models have enjoyed a significant amount of attention from quantitative empirical researchers, with donation-based studies on the rise, but the spotlight on equity has not been as bright. This is in line with the recent legalization of equity crowdfunding in the United States, following the adoption of the Jumpstart Our Business Start-ups (Jobs) Act in 2012.

\section{Table 3}

Academic studies by type of crowdfunding and methodology

\begin{tabular}{|l|c|c|c|c|}
\hline & Conceptual & Empirical: qualitative & Empirical: quantitative & Total \\
\hline Donations & 0 & 0 & 6 & 6 \\
\hline Equity & 1 & 2 & 3 & 6 \\
\hline Lending & 2 & 2 & 15 & 19 \\
\hline Rewards & 1 & 0 & 14 & 15 \\
\hline All models & 18 & 11 & 7 & 36 \\
\hline Total & 22 & 15 & 45 & 82 \\
\hline
\end{tabular}

\section{Table 4}

A chronology of academic studies by type of crowdfunding

\begin{tabular}{|l|c|c|c|c|c|c|c|c|c|}
\hline & $\mathbf{2 0 0 9}$ & $\mathbf{2 0 1 0}$ & $\mathbf{2 0 1 1}$ & $\mathbf{2 0 1 2}$ & $\mathbf{2 0 1 3}$ & $\mathbf{2 0 1 4}$ & $\mathbf{2 0 1 5}$ & $\mathbf{2 0 1 6}$ Feb & Total \\
\hline Donations & & & & & 1 & 2 & 3 & & 6 \\
\hline Equity & & & 1 & & 1 & & 2 & 2 & 6 \\
\hline Lending & & & 4 & 4 & 3 & 5 & 3 & & 19 \\
\hline Rewards & & & & & & 7 & 5 & 3 & 15 \\
\hline All models & 1 & 1 & 3 & 4 & 4 & 8 & 12 & 3 & 36 \\
\hline Total & 1 & 1 & 8 & 8 & 9 & 22 & 25 & 8 & 82 \\
\hline
\end{tabular}

\section{Crowdfunding: Defining the Concept}

The term crowdfunding was coined by Michael Sullivan in 2006, following the launch of fundavlog, a failed attempt at creating an incubator for video blog projects and events (Gaynor et al., 2015). In its few years of existence, the concept has been defined in many ways (Table 5). 
Shortly after it gained traction in the practitioner literature (Ordanini, 2009), the first academic definition of the crowdfunding concept was offered in 2010 by Lambert and Schwienbacher. Those scholars built on the definition of crowdsourcing provided by Kleemann et al. (2008) and extended this to define crowdfunding as "an open call, essentially through the Internet, for the provision of financial resources either in form of donation or in exchange for some form of reward and/or voting rights in order to support initiatives for specific purposes." Other definitions followed, notably those of Mollick (2014) and Belleflamme, Lambert and Schwienbacher (2014). Subsequent authors from various fields were then faced with the choice of adopting one of the definitions already available or offering one of their own, albeit informally (e.g., Colgren, 2014; Lehner, 2014; Ahlers et al., 2015).

As evident from these definitions, the terminology surrounding crowdfunding actors found in academic papers has varied to a great extent, depending mainly on the academic field of the authors and the crowdfunding model being studied. This diversity is expected given the nascent nature of the concept. Most notably, the entities asking for money have been referred to as artists or creators (e.g., Agrawal et al., 2014; Agrawal et al., 2015), entrepreneurs or fund-seeking entrepreneurs (e.g., Belleflamme et al., 2014; Macht, 2014; Gleasure, 2015; Kshetri, 2015), borrowers (e.g., AlAzzam et al., 2012; Burtch et al., 2014), fundraisers (Belleflamme et al., 2015), projects (Meer, 2014), social ventures (Meyskens and Bird, 2015) and founders (Mollick, 2014). At the other end, the entities offering finance have been called funders (e.g., Agrawal et al., 2014; Agrawal et al., 2015; Belleflamme et al., 2014), crowdfunders (Larralde and Schwienbacher, 2012; Burtch et al., 2013; Kuti and Madarász, 2014), investors (e.g., Ahlers et al., 2015; Cholakova and Clarysse, 2015), crowd investors (Lehner and Nicholls, 2014), social investors (Meyskens and Bird, 2015), lenders (Burtch et al., 2014), backers (e.g., Dushnitsky and Marom, 2013; Frydrych et al., 2014, Mollick, 2014) or simply the crowd (Lehner, 2013).

Definitions serve the purpose of isolating the phenomenon from the background by tracing its boundaries and distinguishing it from analogous phenomena. In addition, definitions highlight the most relevant constituent elements. In search of a thorough and fieldwide understanding of the concept, we look at the essential elements that collectively arise from the key definitions found in the literature and attempt to decompose the concept into its main constituents. Thus, the key elements that capture the essence of crowdfunding are:

1. Crowd. Crowdfunding is a subset of crowdsourcing, in that it involves contributions from a large, dispersed audience - that is, a crowd.

2. Funding. Contributions are in the form of financial resources (i.e., money) and are usually small in size.

3. Alternative finance. Crowdfunding is an alternative method for seeking finance, especially in the start-up stage of an entrepreneurial venture. This means it both complements and competes with the venture capital industry. On the one hand, successful crowdfunding campaigns establish the traction and interest of the crowd ahead of the entrance of venture capitalists, thus helping the latter to identify investment opportunities at a lower search cost. On the other hand, as the practice of crowdfunding advances, it may pose a threat to professional investment firms due to its disintermediation nature (Assenova et al., 2016).

4. Models. In exchange, the crowd may receive some form of physical reward as a token of appreciation, a share of equity and voting rights, interest from loans, or the warm glow of satisfaction that comes from giving. 
5. Purpose. Funds are raised for a specific purpose, be it cultural, social or for-profit. Fundraisers are individuals or groups who are often, but not always, entrepreneurs. In certain cases, these individuals are people in need of money for personal reasons, such as health or education purposes.

6. Online. As evident from the definition of Colgren (2014), crowdfunding can be done offline or online. However, since the birth of online crowdfunding platforms, such as Kiva, Kickstarter, DonorsChoose and Indiegogo, academic researchers have focused on the new phenomenon that is the online format of crowdfunding.

Taking each definition into consideration, we find that each of them lacks at least one of the concept's constituent elements (Table 5). To this end, we put forth a definition of our own that we consider to be comprehensive:

Crowdfunding is an alternative model for project financing, whereby a large and dispersed audience participates through relatively small financial contributions, in a purposeful project, in exchange for physical, financial or social rewards. It is usually done via Internetbased platforms that act as a bridge between the crowd and the projects.

This new definition encompasses the elements of the crowd as a large dispersed audience and funding through small financial contributions. It acknowledges that crowdfunding activities are an alternative model of financing a venture and emphasizes the purposeful character of any such project. Moreover, it mentions the different rewards that the crowd may receive in exchange and that represent the different models of crowdfunding. Finally, the online element is highlighted in the reference to the role of Internet-based platforms that act as a bridge between the crowd and the projects. 


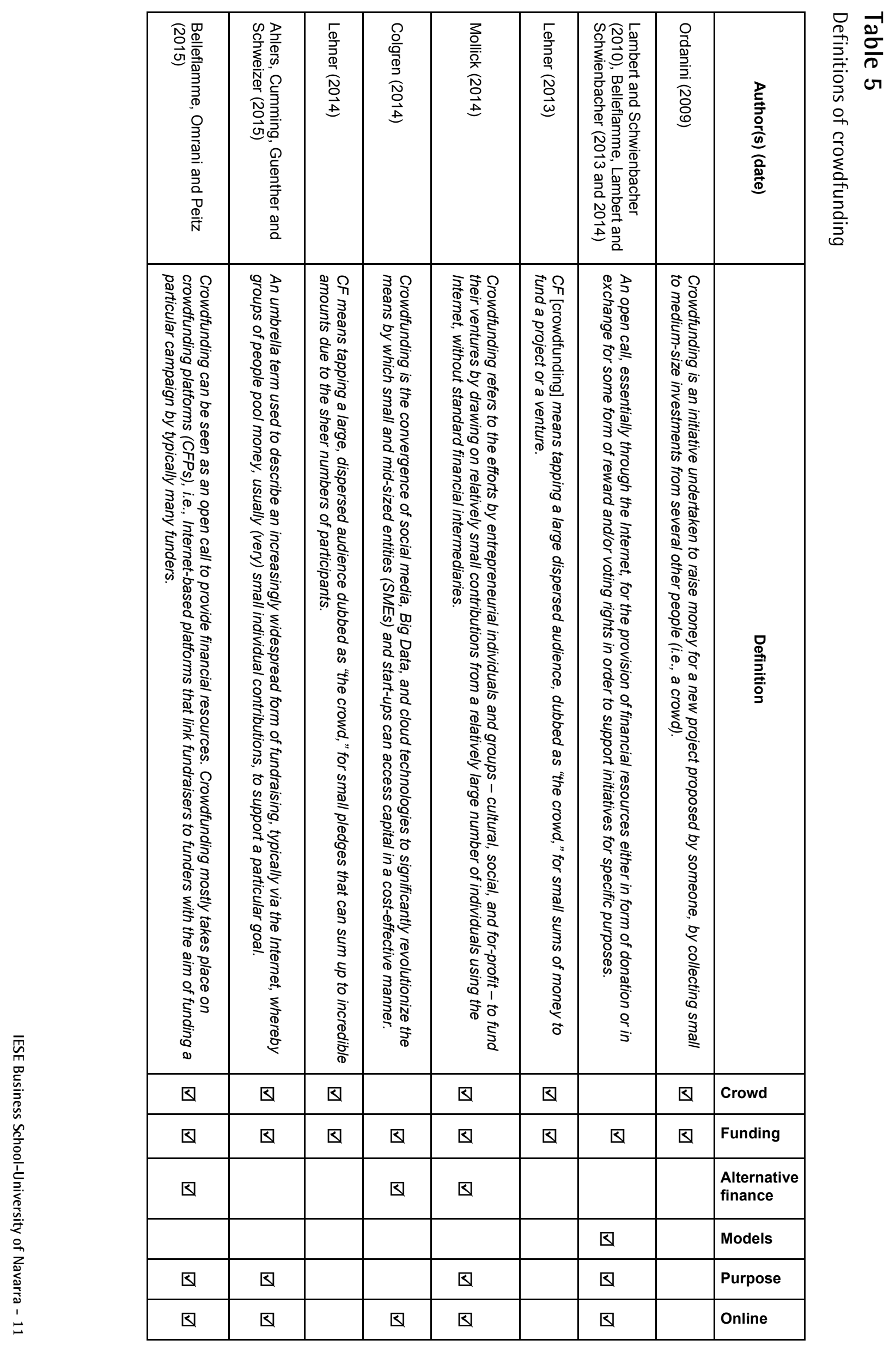




\section{Categorizing the Literature: A Multilevel Approach}

\section{Theoretical Frameworks in Crowdfunding}

As crowdfunding emerges from the descriptive analysis of the literature discussed in the previous sections, scholars from various fields are being drawn into the study of this emerging and exciting phenomenon and so crowdfunding has come to enjoy an interdisciplinary status. This makes it even more challenging to have a command of the literature. Our first task then is to sift through the array of theories used and synthesize them in a meaningful way that allows for the key theoretical perspectives to emerge and their connections to management to be established. We find that these theories can be arranged simultaneously at the level of the crowdfunding model and within the prominent academic domains of economics, sociology and psychology (Table 6). Some papers do not use a specific theory and therefore Table 6 contains only 32 of the 82 papers reviewed.

First, economics - the study of the factors that determine the supply of and demand for goods and services in a market - is a social science that tackles issues such as the asymmetry of information in contracts, the likely consequences of asymmetry and possible remedies. In the management terrain, economics is concerned largely with issues related to the organizational structure, management decisions, entrepreneurship, as well as interactions between firms and the business environment. Both traditional economists and management scholars have enriched the crowdfunding literature with an array of economic theories, from the core theory of information asymmetry to behavioral topics such as herding. Second, sociology - the study of social relationships, social change, and the social causes and consequences of human behavior - has earned an enviable place in the repertoire of management scholars. In general, sociologists investigate the structure of groups, organizations and societies and how people interact within these contexts. Management scholars often adopt a sociological perspective to study business, markets and/or not-for-profit organizations. It is not surprising, then, that several management theories that stem from the field of sociology have been applied in the crowdfunding literature, such as social capital theory. And third, psychology - the study of mind and behavior - focuses on concepts such as perception, cognition, attention and the motivation of humans. In management, studying the mind and behavior of the consumer is a popular topic. In crowdfunding, this consumer is the crowdfunder. The crowdfunders, together with the entrepreneurs, are the protagonists who are studied most often through the psychological lens of the crowdfunding literature. In particular, the cognitive biases and motivations of the fundraisers and funders have been the core focus of a number of scholarly papers on the topic.

Next, having established the profound connections between economics, sociology and psychology and the field of management, we proceed to discuss each of the theories unearthed in the crowdfunding literature and examine how they have been applied in the context of crowdfunding. By doing so, we intend to make apparent the applicability as well as the extension of some key management theories in this setting. 


\section{Table 6}

Management theories in crowdfunding

\begin{tabular}{|c|c|c|c|}
\hline & 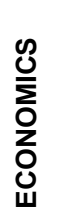 & $\begin{array}{l}\text { ¿̀ } \\
\text { ठ্] } \\
\text { 응 } \\
\text { ర্ }\end{array}$ & 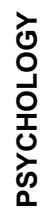 \\
\hline Information asymmetry (Agrawal et al., 2014 and 2016; Belleflamme et al., 2014 and 2015) & $\square$ & $\square$ & $\square$ \\
\hline Agency theory (Ley and Weaven, 2011) & 甲 & $\square$ & $\square$ \\
\hline Contract failure (Belleflamme et al., 2013) & $\square$ & $\square$ & $\square$ \\
\hline Signaling theory (Lin et al., 2013 and 2014; Moss et al., 2014; Ahlers et al., 2015) & $\square$ & $\square$ & $\square$ \\
\hline Game theory: equilibrium selection (Corazzini et al., 2015) & $\square$ & $\square$ & $\square$ \\
\hline Theory of charitable giving (Ly and Mason, 2012) & $\square$ & $\square$ & $\square$ \\
\hline Network externalities (Li and Duan, 2014) & $\square$ & $\square$ & $\square$ \\
\hline Economic models of social influence (Burtch et al., 2013) & 甲 & $\square$ & $\square$ \\
\hline Social influence (herding) (Zhang and Liu, 2012; Smith et al., 2015) & 甲 & $\square$ & $\square$ \\
\hline Category membership (Leung and Sharkey, 2014) & $\square$ & $\square$ & $\square$ \\
\hline Institutional theory (Kshetri, 2015; Rivera-Santos et al., 2015) & $\square$ & $\square$ & $\square$ \\
\hline Social capital theory (Lehner, 2014; Colombo et al., 2015; Zheng et al., 2014) & $\square$ & $\square$ & $\square$ \\
\hline Impression management (Gleasure, 2015) & $\square$ & $\square$ & $\square$ \\
\hline Commitment-trust theory (Macht, 2014) & $\square$ & $\nabla$ & $\nabla$ \\
\hline Cognitive evaluation theory (Allison et al., 2015; Cholakova and Clarysse, 2015) & $\square$ & $\square$ & घ \\
\hline Decision-making biases (Pope and Sydnor, 2011; Jenq et al., 2012; Lin et al., 2014) & $\square$ & $\square$ & $\square$ \\
\hline Motivations (Gerber et al., 2012; Lehner and Nicholls, 2014; Hildebrand et al., 2014) & $\square$ & $\square$ & 甲 \\
\hline
\end{tabular}

The theory of information asymmetry first appeared in the seminal works of George Akerlof (1970) and Michael Spence (1973) as a plausible explanation for common phenomena that mainstream equilibrium economics could not explain. Information asymmetry theory deals with the study of decisions in transactions where one party has more or better information than the other. This asymmetry in information causes an imbalance of power in transactions and, when severe enough, can cause the transactions to come to a halt, leading to market failure. There is a high degree of information asymmetry in crowdfunding because of the practical difficulties and high costs involved, not to mention the reluctance of the borrowers when it comes to the public disclosure of huge amounts of information about themselves and their projects on online platforms.

Most commonly, information asymmetries are studied in the context of principal-agent problems, also known as agency theory. The principal-agent problem occurs when one person or entity (the agent) is able to make decisions that affect another person or entity (the principal) but the incentives of the two entities are not fully aligned. Then, in circumstances where there is 
asymmetric information in that the agent has more information than the principal, the principal cannot directly ensure that the agent is always acting in the principal's best interest. Consequently, the principal may become sufficiently concerned at the possibility of being exploited by the agent that he or she chooses not to enter into the transaction at all, thereby foregoing any mutual benefits in favor of the suboptimal outcome of no transaction that lowers overall welfare. Such a deviation from the principal's interest by the agent is called agency cost.

In a first attempt to highlight agency costs in crowdfunding, Ley and Weaven (2011) extend agency theory in the context of start-up equity crowdfunding and decipher the necessary control mechanisms in the investor-investee relationship. The authors categorize these mechanisms into four subsections - namely, investor-specific factors, ex ante and ex post investment factors, and the impact of crowdfunding. In this setting, the principal is the investor and the agent is the borrower. To name a few controls, the authors find that agency costs are mitigated when the crowd is composed of suitably informed and experienced investors, the borrowers have a trusted network of those who can act as referees, there is no requirement that sensitive information be distributed to the crowd of investors, the crowd's contractual rights are delegated to an external intermediary capable of making decisions, the crowd is allowed to maintain representation on the venture's Board, the deal has a limited economic life, and an exit from the deal can be achieved quickly (Ley and Weaven, 2011).

Moreover, as a result of information asymmetry, the crowd faces a number of asymmetric information problems - namely, adverse selection and moral hazards. First, information asymmetry may lead to adverse selection when the information provided by the lender is insufficient for the investor to make an informed decision. Adverse selection theory has been expanded in several directions, such as by making the information structure endogenous (so the agent can decide whether or not to gather private information) and by taking into consideration social preferences and bounded rationality. In crowdfunding, there is adverse selection insofar as funders may lack the necessary information to estimate the proposed campaigns' chances of success. Second, moral hazard problems may also arise in crowdfunding, as funders may be unable to monitor how fundraisers use the funds after these have been collected. Along these lines, Agrawal et al. (2014) examine the market dynamics of the crowdfunding marketplace and explore adverse selection and moral hazards in this context. Further, Belleflamme et al. (2015) study the economic forces at play that can explain the design of crowdfunding platforms and offer potential remedies for information asymmetry problems, as do Agrawal et al. (2016), who propose the use of syndicates - a model borrowed from the venture capital industry - in equity crowdfunding. Moreover, Belleflamme et al. (2014) employ information asymmetry, industrial organization and price discrimination to compare two forms of crowdfunding, from the entrepreneur's point of view. Interestingly, through the application of these theories, the authors dispute previous literature, regarding how donations arise due to altruistic motivations. In their scenario, crowdfunders donate because they expect to become consumers in the future or enjoy sufficient community benefits.

Information asymmetry can also lead to contract failure. In economics, contract theory studies how economic actors construct contractual arrangements in the presence of asymmetric information by estimating utility functions and calculating optimal decisions. Information asymmetry inhibits the consumer from accurately evaluating the quality of the good, and this in turn creates room for the producer to lie by offering lower quality. In this way, contract failure may lead to market failure, and for this reason contract failure is an explanation for the existence of nonprofit organizations since, when such situations occur, nonprofits are expected to step in and provide the necessary good or service in response to market failure. Nonprofit corporations are considered more trustworthy since they are structured in ways that lack incentives to cheat.

14 - IESE Business School-University of Navarra 
To this end, Belleflamme et al. (2013) artfully apply contract failure theory to explain why notfor-profit organizations may be more successful in using crowdfunding than corporations or freelancers.

In order to combat information asymmetry, economic scholars conceived the theory of signals (Spence, 1973). Signaling involves the agent credibly conveying some information to the principal. For example, job candidates could signal their knowledge and skills to a potential employer through the attainment of a credible university degree. This theory is useful for describing behavior when two entities have access to different information (Spence, 1973; Connelly et al., 2011). In signaling, the informed entity moves first by deciding whether and how to communicate, or signal, information. The other entity must then choose how to interpret the signal. Given the high degree of information asymmetry that is inherent in deciding in which crowdfunding projects to invest, signaling theory has proved to be a useful lens for examining investment decisions in crowdfunding and consequently it has been chosen as a theoretical framework in many of these papers. In particular, signaling theory has been successfully applied in equity, lending and reward contexts. In lending, Lin et al. (2013) find support for the central premise of signaling theory that agents facing asymmetric information adapt by using signals to mitigate adverse selection. Moreover, Moss et al. (2014) extend signaling theory to the microfinance market, thereby building on the existing literature on the importance of signaling in the face of information asymmetry. Ahlers et al. (2015) research the project signals and attributes of venture quality that are most likely to induce investors to commit financial resources in an equity crowdfunding context. Finally, for rewards, Lin et al. (2014) combine herding and signaling theories and manage to reconcile the two perspectives by highlighting that the behavior of other crowdfunders may also serve as a project quality signal for others, provided that the crowdfunder fits a specific type.

Furthermore, in the list of economic theories applied to crowdfunding, there is also game theory and, more specifically, equilibrium selection in games. Game theory is the study of mathematical models of conflict and cooperation between rational players. Equilibrium selection is a concept from game theory that addresses the reasons why players select one equilibrium over another (Corazzini et al., 2015). According to the literature, the presence of multiple options on a crowdfunding platform, with little to differentiate among them, greatly affects the level of contributions and chances of fundraising success, because a multiplicity of options makes coordination between players increasingly difficult. Corazzini et al. (2015) are the first to explore the problem of coordination among investors using equilibrium selection in games, and their research leads them to some interesting practical findings on how platforms can help overcome this coordination issue.

Moreover, through the lens of the economic theory on charitable giving, Ly and Mason (2012) investigate what types of projects individuals perceive as most effective. The economic theory of charitable giving distinguishes between pure and impure altruism (Andreoni, 2006). Pure altruism is about "people's desire to contribute to the public good" (Ly and Mason, 2012), placing a high value on the "outcome of charity, such as increases in the welfare of poor beneficiaries. However, donors also care about their own contribution because they derive utility from donating," which is labelled impure altruism. Like charitable giving, lending through crowdfunding platforms may reflect a mix of pure and impure altruism. "Then, if poverty alleviation is an important objective for lenders, they may seek to make a difference by targeting borrowers they perceive as the poorest and most vulnerable, to maximize the impact of their contribution" (Ly and Mason, 2012). 
Indeed, the authors cited find that loans to women and large groups are funded more quickly and that the amount of the loan and the repayment term matters to investors.

In addition, Li and Duan (2014) examine the role of network externalities in the context of crowdfunding and extend the traditional static view of the model by incorporating the timing of achieving a certain network size. A network externality is the change in the benefit that an agent derives from a good when the number of other agents consuming the same kind of good increases. A positive network externality implies that the value of a good is dependent on the number of other users. In this case, the bigger the crowd that accesses a particular crowdfunding platform, the more valuable the platform becomes for each fundraiser. In turn, more projects are listed on the platform and the value of the platform increases for each crowdfunder. The theory also suggests that network effects become significant after a certain number of users - termed critical mass - has been achieved. At the critical mass point, the value obtained from the good is greater than or equal to the price paid for the good. Because the value of the good is determined by the user base, this implies that, after a certain number of people have bought the good, additional people will buy the good due to the value exceeding the price. With regard to a particular project in the process of raising funds through an online platform, Li and Duan (2014) show that achieving critical mass in a timely manner is crucial for successfully raising the target funding. The theoretical mechanism is the interplay between positive network externalities and negative time effects that determines an investor's propensity to provide support. In a different study, Saxton and Wang (2014) provide evidence for the power of the social network effect that is, the size of an organization's network of followers or fans - by developing a model that explains the factors determining social media donations. Through its online fans, an organization can reach a greater number of prospective donors, spread awareness of its causes and needs, and rally financial support through social pressure (Saxton and Wang, 2014).

Economics and sociology come together in the economic models of social influence. A key factor that can influence the behavior of lenders is publicly available information on prior contribution behavior, including the amount and timing of others' contributions. "The directionality of social influence stemming from information on prior contributions in online networks is not easily inferred for a given marketplace" (Burtch et al., 2013). This is because the direction of influence depends on a variety of factors, including the incentives of the investors, their status and social importance, and the transparency of their decisions. A number of these factors are potentially at play in a crowdfunding market. Investors may be driven by a sense of altruism to help the lender and support others who might benefit from the project, they may have a personal interest in the proposed project, or may be concerned about their social image.

Burtch et al. (2013) employ the economic models of reinforcement and substitution to decipher the directionality of this social influence - that is, the effects that others' prior contribution decisions have on later participants' contribution decisions, in a donation-based crowdfunding market. According to economic theory, when there is social influence arising from information on prior contributions, there are two competing classes of economic models that can explain funding behavior toward public goods (Shang and Croson, 2009). First, reinforcement models predict that larger initial contributions will have a positive effect on later contributions, through the mechanisms of reciprocity, fairness and social norms. The reinforcement model speaks to the need to contribute fairly, rather than leave others to bear the burden of supporting the public good on their own (Burtch et al., 2013). Second, substitution models predict that initial contributions will have a negative effect on later contributions and will be followed by crowding out once the level of others' contributions rises to meet the need of the public good. In this case, individuals will tend to reallocate their funds more toward private consumption activities, thereby

16 - IESE Business School-University of Navarra 
crowding out from the public project (Andreoni, 1990). Burtch et al. (2013) "find evidence in support of a substitution model, which suggests a partial crowding-out effect" of the magnitude of a $0.31 \%$ decrease in subsequent contribution for an increase of $1 \%$ in the prior frequency of contribution. This means that "contributors may experience a decrease in their marginal utility from making a contribution as it becomes less important to the recipient," which suggests that altruism is a key incentive to contribute in this marketplace (Burtch et al., 2013).

In behavioral economics, the branch of economics that studies the effects of social and psychological factors on decision making, herding behavior is the phenomenon of individuals deciding to imitate others rather than deciding independently on the basis of their own information. Herding theory has its roots in Keynes, who conceived of herding as a response to uncertainty and individuals' perceptions of their own ignorance (Keynes, 1930). According to Keynes (1930), herding usually emerges as a result of social learning, reputation concerns or iterative thinking. In a world of uncertainty, we follow others because they may be better informed or due to the social pressure of conformity - that is, it is better, in terms of reputation, to be conventionally wrong than unconventionally right. In the context of crowdfunding, peer effects or herding manifest themselves as the effects of social influence by others' prior funding decisions. Funders' propensity to invest in a given project is likely to increase as that project visibly accumulates capital, since the amount of capital raised conveys information about what others believe about the quality of the project and the founder's abilities.

Smith et al. (2015) study peer effects in charitable giving by investigating how the amount that donors give is affected by donations made by others in their peer group and, in accordance with theory, they found positive and sizable peer effects. Zhang and Liu (2012) examine peer effects in lending environments and discover that, instead of passively mimicking their peers (irrational herding), lenders engage in active observational learning (rational herding). In other words, lenders tend to infer the creditworthiness of borrowers by observing peer lending decisions and use publicly observable borrower characteristics to moderate their inferences. Interestingly, rational herding beats irrational herding in predicting loan performance, according to Zhang and Liu. Moreover, Lin et al. (2014) look into the types of crowdfunders in a reward-based environment and identify four distinct types - namely, the active backers, the trend followers, the altruistic, and the crowd. Their study shows that crowdfunders who consciously follow trends are more susceptible to herding behavior, while crowdfunders who are more altruistic tend to invest in order to help project creators. This shows that recognizing the fundamental differences between different types of lenders is important to understanding which theoretical perspectives are applicable to the appropriate group of lenders.

Moreover, research in economic and organizational sociology has demonstrated that category membership is highly influential in market settings, shaping how individuals and firms are perceived and thereby affecting a wide range of economic outcomes (Zuckerman, 2000; Ruef and Patterson, 2009). Because consumers and evaluators use category labels to identify and make sense of individuals and products, category labels play a key role in audience perceptions. Notably, market actors who span multiple social categories tend to be devalued relative to their more specialized peers. However, some scholars contend that perceptual factors - namely, the difficulties that buyers have in making sense of category spanners - contribute to the observed pattern of devaluation. Others argue that the penalty for category spanning stems from the fact that those who do not focus their efforts narrowly tend to offer products that are of lower quality. In the hopes of fostering a sense of community, crowdfunding websites often allow participants to establish and/or join self-organized groups. As a result, borrowers on the site may choose to 
join a group. These virtual groups are established by a self-appointed "group leader" who is responsible for classifying the group into various categories. These categories serve to signify the group's identity and are used to help potential new members seeking an appropriate group to join as well as to assist lenders in identifying potential borrowers with whom they may have an affinity. Consequently, an individual borrower may be a member of a group that is classified in multiple categories. Leung and Sharkey (2014) look at such cases on Prosper.com and find that category spanning is perceived negatively and can result in devaluation, even in the absence of any underlying quality differences.

In addition, the theory of institutional logic, a core concept in sociology and organizational studies looks at the influence of beliefs on behavior. An institutional logic is the set of material practices and symbolic systems "including assumptions, values, and beliefs, by which individuals and organizations provide meaning to their daily activity, organize time and space, and reproduce their lives and experiences" (Thornton, Ocasio and Lounsbury, 2012). In crowdfunding, while the online platforms tend to eliminate most of the distance-related sources of economic friction such as monitoring progress and information gathering, they do not eliminate social friction. Therefore, the effect of both formal institutions, such as clearly defined rules and regulations, and informal institutions, such as social networks and interpersonal trust, can be significant for the successful funding of a project. Institutions can encourage entrepreneurship and protect investors, thereby reducing the uncertainty that crowdfunding actors face in this environment. To this end, Kshetri (2015) applies institutional theory to develop propositions on how the context provided by formal and informal institutions matters for a crowdfunding campaign, and how these institutions are likely to affect the success of crowdfunding projects. Rivera-Santos et al. (2015) also use institutional theory to understand the relationship between social enterprises and their environments.

Moreover, social capital theory suggests that the social networks in which individuals are embedded can facilitate resource exchange and knowledge sharing through three different routes - namely, the structural dimension of network ties, the relational dimension or trust, and the cognitive dimension of shared narrative (Nahapiet and Ghoshal, 1998). Based on the theory of multidimensional social capital, Zheng et al. (2014) develop a theoretical model to examine the effects of social capital's three dimensions on project performance and find that social capital is a valuable asset in reward-based crowdfunding. Lehner (2014) also relates social capital theory to crowdfunding and finds that the nexus of opportunity and entrepreneur is breached in this context because of the constant exchange of ideas with the crowd. As Lehner (2014) explains, there is an interplay of the various forms of social capital in the processes of recognition, formation and exploitation in crowdfunded ventures. For instance, interaction with the crowd may induce reconsideration of the original opportunity, while sourcing from the crowd may help shape the actual opportunity together with the crowd and spread information at the same time. These findings have been a valuable contribution to entrepreneurship literature. In addition, in the context of reward-based crowdfunding and using social capital theory, Colombo et al. (2015) find that internal social capital is fundamental to attracting capital and backers in the early stages of a campaign. In turn, these early contributions are closely associated with the likelihood of a project reaching its target capital, so a head start fully mediates the effect of internal social capital on a campaign's success. Hence, besides personal social contacts, social contacts built within crowdfunding communities may also be a vehicle to attract seed financing (Colombo et al., 2015). This is particularly important as crowdfunding platforms appear to develop progressively into environments rich in social interactions, norms and behaviors.

Furthermore, since social capital is seen as an important asset for entrepreneurs, this implies that the way entrepreneurs manage their public image is crucial to their success. In turn, this suggests that the level of public exposure and information disclosure required by crowdfunding may be a

18 - IESE Business School-University of Navarra 
meaningful concern for entrepreneurs. Impression management is the effort to control or influence other people's perceptions. The theory of impression management can be used to explain how individuals use their personal appearance and the tone of their interactions to control others' perceptions of them and to elicit desired attributions (Dillard et al., 2000). To this end, Gleasure (2015) investigates how concerns about impression management may explain resistance to resorting to crowdfunding. Based on the model of resistance developed by Kim and Kankanhalli (2009), Gleasure (2015) employs the lens of impression management to explain entrepreneurs' resistance to crowdfunding as being influenced by the "entrepreneurs' fear of disclosure, fear of visible failure, and fear of projecting desperation."

In addition, Macht (2014) examines the value-adding benefits of crowdfunding through a relationship marketing lens and, specifically, commitment-trust theory. The theory rests on the premise that the existence of trust in a relationship creates commitment, cooperation and a long-term relational exchange (Morgan and Hunt, 1994). The theory was originally developed in the context of offline relationships and predicts that communication, minimization of opportunistic behavior, and shared values determine the level of trust. In the context of crowdfunding, Macht (2014) argues that the value-adding benefits of crowdfunding may go beyond the one-off financial transaction portrayed in most academic papers, as borrowers require some form of activity from backers, during or even after the fundraising period. For instance, backers may promote the project among their own contacts via social media, or entrepreneurs may ask backers for feedback. Therefore, if they wish to draw on backers' resources again in the future, entrepreneurs have to build and maintain long-term, ongoing relationships. Moreover, Macht (2014) reasons how, in the context of online crowdfunding, additional factors will determine the level of trust between borrowers and lenders - namely, security of the website, data privacy and recommendations of borrowers through trusted parties.

Furthermore, cognitive evaluation theory asserts that extrinsic motivation, such as monetary rewards, overcomes intrinsic motivation by diminishing the satisfaction individuals receive for actions in which they would otherwise engage (Deci and Ryan, 2000 and 2012). While cognitive evaluation is a theory framed in terms of rewards that may undermine intrinsic motivation, selfdetermination theory is framed in terms of factors that may facilitate intrinsic motivation (Deci and Ryan, 2000). Allison et al. (2015) extend the application of cognitive evaluation and self-determination theories to the crowdfunding microfinance context by suggesting that the intrinsic motivation of lenders to provide capital is undermined when entrepreneurs focus on future extrinsic rewards. Looking at Kiva.org, they observe how the framing of individual microloan narratives varies across entrepreneurs. The authors then discover that, contrary to the predictions of cognitive evaluation theory, the effect of intrinsic cues is stronger than the effect of extrinsic cues, in that lenders respond positively to narratives that highlight the venture as an opportunity to help others, and less positively when the narrative is framed as a business opportunity. The rationale is that, unlike the situation with traditional investors, the intrinsic motivation of crowd lenders is high as they self-select in the crowdfunding marketplace to provide funds to needy entrepreneurs without the possibility of future financial rewards.

Similarly, Cholakova and Clarysse (2015) investigate the relative role of financial and nonfinancial motives in both equity and reward-based crowdfunding, as well as the impact that the juxtaposition of these two motives may have on crowding out investors' interest in rewardbased campaigns. Their results show how different motives play out differently in the various crowdfunding settings. Furthermore, contrary to cognitive evaluation theory where the presence of extrinsic motivators is expected to crowd out intrinsic motivation, these authors find that 
participants who initially invested in the project for equity were significantly more likely to keep a funding pledge for it as well, rather than redistribute their investment in the equity campaign only. Hence, Cholakova and Clarysse (2015) conclude, the bundling of financial and nonfinancial incentives in crowdfunding campaigns can be an effective new strategy for raising finance on the platforms.

In the area of cognition, biases often creep up in decision making. As the complexity of a situation increases, heuristics - or mental "rules of thumb" (Tversky and Kahneman, 1974) - are often used to simplify decisions. Scholars have categorized heuristics into three main groups - namely, representativeness, availability, and adjustment and anchoring (Kahneman and Tversky, 1974). Each category has a list of biases associated with it. For example, the representativeness heuristic is linked to overconfidence bias and availability is associated with illusory correlation, where two events that are strongly associated are judged as occurring together more frequently. In crowdfunding, the complexity of picking a project in which to invest may cause crowdfunders to use a rule of thumb for assessing the chances of success. In this case, various biases may appear in decision making even when individuals are engaging in prosocial behavior, similar to the findings of Jenq et al. (2012) regarding discrimination on the basis of physical attributes. Moreover, Pope and Sydnor (2011) find significant biases against listings without a picture and listings with pictures of black people, older individuals, and people who appear unhappy. In addition, Lin et al. (2014) find that, in lendingbased environments, lenders tend to prefer to invest in projects located in the same geographical area, often forgoing better alternatives that carry a lower risk and higher return but are located in geographically more distant areas.

Finally, the psychological motives behind participation in crowdfunding have interested many researchers as these differ markedly from motives for engaging in traditional financing. Notably, Gerber et al. (2012) investigate what motivates participation in crowdfunding and how platform designers can use motivational needs to influence the behavior of the various actors. In addition to the expected extrinsic motivators, such as securing funding for entrepreneurs and early consumption for funders, the authors find that intrinsic motivators also play a role. In particular, social interactions and feelings of being connected to a community with similar interests and ideals seem to be a strong motivator (Gerber et al., 2012). Lehner and Nicholls (2014) also look at the motivations of crowdfunding actors, this time in order to discover why an efficient social finance market has yet to be created, while Hildebrand et al. (2014) examine incentives in the lending market and provide evidence of perverse incentives in crowdfunding that are not fully acknowledged by the market.

In conclusion, in response to our research question on the theoretical perspectives adopted in the crowdfunding literature, we have uncovered 17 theories stemming from the fields of economics, sociology and psychology that have been applied and extended successfully in this context. Furthermore, through the application of these theories, researchers have been able to examine questions concerning not only the theoretical mechanisms governing this process but also the practical implications of various factors involved that determine to some extent the success or failure of a particular crowdfunding campaign. In the next section, we turn our attention to these success factors and aim to synthesize them in a meaningful way. 


\section{Empirical Factors for Crowdfunding Success}

The second part of our research question concerns the different factors that contribute to the success of a crowdfunding campaign. Before setting out to uncover the success factors behind a crowdfunding project, we first need to articulate clearly what we mean by success in this context. To this end, we divide success in crowdfunding into two stages: in the first, success entails raising the requested amount of money, followed by successful completion of the terms of the exchange in the form of the repayment promised. On top of that, the success of crowdfunding campaigns passes through the hands of the crowd and, what is more, it is contingent on the smooth running of the entire crowdfunding marketplace that hosts these transactions. Therefore, crowdfunding success is a function of the four main dimensions of funding, repayment, the crowd and the market. At the same time, campaigns differ in their fundamental characteristic, which is the type of reward they offer to the crowd, and this in turn defines the very nature of the campaign itself, the crowd it addresses, and the segment of the market with which it deals. So, what makes a crowdfunding campaign successful?

To answer this important question, we surveyed the literature, analyzed the main findings and synthesized our conclusions into the four main dimensions that determine success for a crowdfunding campaign: funding success, repayment success, the crowd and the market. Under each dimension, we derived the key factors that contribute to success as documented in the literature to date, and organized these factors according to the type of crowdfunding model. Table 7 offers a tabulation of the scholarly findings according to success dimension, success factor and crowdfunding model. For funding success, a common factor across models is the design of the project campaign, which includes decisions such as the language used to describe the project and its economic value compared with its social value, and the characteristics of the entrepreneurs, such as their business acumen, social network and gender. In addition, the effect of competition among projects on the likelihood of funding success is addressed in the context of donations. For repayment success, the key factors that appear are the design of the campaign, the characteristics of the entrepreneur, and the effect of technology on the probability of repayment. Furthermore, with regard to the behavior of the crowd, the motivations, biases, herding tendencies, geography and culture are the success factors that have been researched to date. For the fourth dimension, the market, scholars have talked about risks in equity crowdfunding and information privacy in reward-based crowdfunding. We proceed to discuss the scholarly findings for each factor in the four dimensions, and organize our discussion in terms of the crowdfunding model. In this way, by explicitly reporting the specific factors that have been found to contribute to the success of crowdfunding campaigns, we are able to ascertain corroboratory findings and locate conflicting results. 


\section{Table 7}

Scholarly findings according to success parameter and crowdfunding model

\begin{tabular}{|c|c|c|c|c|}
\hline & $\begin{array}{l}\text { FUNDING } \\
\text { SUCCESS }\end{array}$ & $\begin{array}{l}\text { REPAYMENT } \\
\text { SUCCESS }\end{array}$ & THE CROWD & THE MARKET \\
\hline 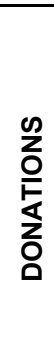 & $\begin{array}{c}\text { Design } \\
\text { (Meer, 2014; Saxton and Wang, } \\
\text { 2014; Meyskens and Bird, 2015; } \\
\text { Gorbatai and Nelson, 2015) } \\
\text { Entrepreneur } \\
\text { (Saxton and Wang, 2014) } \\
\text { Competition } \\
\text { (Meer, 2014; Corazzini et al., } \\
\text { 2015) }\end{array}$ & Not applicable & $\begin{array}{c}\text { Motivations } \\
\text { (Burtch et al., 2013) } \\
\text { Herding } \\
\text { (Smith et al., 2015) }\end{array}$ & \\
\hline そૅ & $\begin{array}{c}\text { Design } \\
\text { (Meyskens and Bird, 2015; } \\
\text { Ahlers et al., 2015) } \\
\text { Entrepreneur } \\
\text { (Ahlers et al., 2015) }\end{array}$ & & $\begin{array}{c}\text { Motivations } \\
\text { (Cholakova and Clarysse, } \\
\text { 2015) } \\
\text { Geography } \\
\text { (Agrawal et al., 2015) }\end{array}$ & $\begin{array}{c}\text { Risks } \\
\text { (Ley and Weaven, } \\
\text { 2011; Stemler, } \\
\text { 2013; Agrawal et } \\
\text { al., 2016; Baucus } \\
\text { and Mitteness, } \\
\text { 2016) }\end{array}$ \\
\hline Ju & $\begin{array}{c}\text { Design } \\
\text { (Galak et al., 2011; Ly and } \\
\text { Mason, 2012; Allison et al., 2013; } \\
\text { Lin et al., 2013; Leung and } \\
\text { Sharkey, 2014; Meyskens } \\
\text { and Bird, 2015) } \\
\text { Entrepreneur } \\
\text { (Bruton et al., 2011; Jenq et al., } \\
\text { 2012; Ly and Mason, 2012; } \\
\text { Allison et al., 2013; Lin et al., } \\
\text { 2013; Moss et al., 2014; Allison } \\
\text { et al., 2015) }\end{array}$ & $\begin{array}{c}\text { Design } \\
\text { (Al-Azzam et al., 2012; } \\
\text { Moss et al., 2014) } \\
\text { Entrepreneur } \\
\text { (Al-Azzam et al., } \\
\text { 2012) } \\
\text { Technology (Al- } \\
\text { Azzam et al., 2012) }\end{array}$ & $\begin{array}{c}\text { Biases } \\
\text { (Pope and Sydnor, 2011; } \\
\text { Galak et al., 2011; Jenq et } \\
\text { al., 2012; Burtch et al., 2014; } \\
\text { Morse, 2015) } \\
\text { Herding } \\
\text { (Zhang and Liu, 2012) } \\
\text { Geography } \\
\text { (Lin and Viswanathan, 2014) }\end{array}$ & \\
\hline 总 & $\begin{array}{c}\text { Design } \\
\text { (Meyskens and Bird, 2015; } \\
\text { Frydrych et al., 2014; Cumming } \\
\text { et al., 2015; Colombo et al., 2015; } \\
\text { Xu et al., 2016) } \\
\text { Entrepreneur } \\
\text { (Mollick, 2014; Zheng et al., 2014; } \\
\text { Mollick and Kuppuswamy, 2014; } \\
\text { Marom et al., 2015; Mollick and } \\
\text { Robb, 2016) }\end{array}$ & $\begin{array}{c}\text { Design } \\
\text { (Mollick, 2014) }\end{array}$ & $\begin{array}{c}\text { Herding } \\
\text { (Lin et al., 2014; Zhang and } \\
\text { Liu 2012; Li and Duan, 2014; } \\
\text { Kuppuswamy and Bayus, } \\
\text { 2015) } \\
\text { Culture } \\
\text { (Zheng et al., 2014) }\end{array}$ & $\begin{array}{c}\text { Privacy } \\
\text { (Burtch et al., 2015) }\end{array}$ \\
\hline
\end{tabular}

Donations. The crowdfunding literature on donations finds that funding success is influenced by the design of the campaign, the characteristics of the entrepreneur and competition. With respect to choosing the donation model for a campaign, Meyskens and Bird (2015) indicate that this model is appropriate when a social venture creates high social value but low economic value. In such cases, this design is suitable for attracting investors who are interested in acting as philanthropists and do not expect any type of financial return. In terms of the language used, Gorbatai and Nelson (2015) find that female linguistic patterns are preferred over male patterns, leading to a reversal in gender inequality with respect to traditional funding. Positive sentiment, vividness and inclusive language are both more likely to be rewarded in crowdfunding campaigns and more likely to be used by women, while the use of language related to money, which is more likely to be used by men, has a higher chance of being penalized (Gorbatai and Nelson, 2015). Moreover, Meer (2014) finds that the efficiency price of giving (i.e., how much of the donation 
reaches its destination) has a strong impact on the likelihood of a project achieving its funding goal, in that a $10 \%$ increase in the price of giving results in the likelihood of a project being funded being about 3.6\% lower. In addition, Saxton and Wang (2014) find that, in the social networking environment, donors are not sensitive to variation in levels of organizational efficiency, which contradicts previous studies of offline donations.

With respect to the entrepreneurs, the size of their social network matters, as Saxton and Wang (2014) show. Social network factors appear to take precedence over traditional economic explanations as attention-getting projects and social pressures drive funding contributions more than concerns over efficiency. And with regard to competition from other campaigns, studies show that competition has the expected negative effect on giving - in fact, increased competition reduces the likelihood of a project being funded by 1.9\% to 5.3\% (Meer, 2014). Along the same lines, Corazzini et al. (2015) deal with the coordination problem that arises as the number of other project options increases. Their results reveal a possible remedy - much of the coordination problem introduced by multiplicity may be eliminated if donor attention is directed toward a single contribution option, provided that this option is perceived by donors as the most promising. This will be the case if fundraising sites feature projects based on their merits.

Moreover, the literature on donations also addresses the behavior of the crowd from numerous angles. First, the crowd's motivation seems to play an important role in overall campaign success. Burtch et al. (2013) find a partial crowding-out effect in contributions - an increase of $1 \%$ in the prior frequency of contribution is associated with a $0.31 \%$ decrease in subsequent contribution. This means that contributors experience "a decrease in their marginal utility from making a contribution as it becomes less important to the recipient," which suggests that altruism is a key incentive to contribute in this donation-based marketplace. Also, contributions to crowdfunding projects, even in markets where crowdfunding is driven by altruism, appear to be attracted to quality projects (Burtch et al., 2013). Second, the crowd's herding behavior is also examined by Smith et al. (2015), who find positive and sizable peer effects in that higher average donations cause people to increase the amount that they give - a £10 increase in the mean of past donations causes people to give $£ 2.50$ more on average.

Equity. Funding success in equity crowdfunding is reportedly influenced by the design of the campaign and the characteristics of the entrepreneur. Meyskens and Bird (2015) indicate that the entrepreneur should opt for the equity model when there is high economic value and low social value, since equity investors seek a return on their investments and generally place greater emphasis on economic compared with social value. Another study dealing with design factors by Ahlers et al. (2015) finds that retaining the venture's equity, as well as providing more detailed information about risks, can be interpreted as effective signals of funding success. As far as the entrepreneur is concerned, the same authors find that social capital and intellectual capital have little to no impact on funding success (Ahlers et al., 2015).

Crowd behavior is also important in the equity setting. Concerning the motivations for investing in equity crowdfunding, Cholakova and Clarysse (2015) find these to be restricted to financial returns. However, other factors also seem to affect the behavior of the crowd, particularly geography. Geography affects crowd behavior in an important way. The crowd is less affected by geographic proximity than in traditional entrepreneurial financing - Agrawal et al. (2015) find that "the average distance between artist-entrepreneurs and investors is about 3,000 miles, suggesting a reduced role for spatial proximity." However, distance still plays a role in crowdfunding insofar as "local investors invest relatively early, and they appear less responsive 
to decisions by other investors" (Agrawal et al., 2015). In other words, local investors are less liable to herding behavior and so geographic proximity may mitigate herding.

With respect to the market, several scholars have investigated the presence of risks. Given the combination of unsophisticated investors, inherently risky businesses, and the novelty of regulations, equity crowdfunding is to be approached with caution (Stemler, 2013). Start-ups with high information sensitivity, complex due diligence requirements, and a long duration before an available exit are deemed unsuitable candidates for accessing finance through crowdfunding (Ley and Weaven, 2011). In order to mitigate risk then, the crowd should be composed of suitably informed and experienced investors, an initial deal screening process must take place, there must be external deal referrals from a trusted network, sensitive information should not be required or distributed to the crowd of investors, and investment deals must not have complex due diligence requirements (Ley and Weaven, 2011). In addition, the crowd's contractual rights should be delegated to an external intermediary capable of making decisions but the crowd should maintain representation on the venture's Board, provided that the portfolio companies do not require follow-on funding. Moreover, deals should have exits that are reached quickly or where optimal exits are predetermined (Ley and Weaven, 2011).

Baucus and Mitteness (2016) provide examples of fraud from cases of Ponzi entrepreneurs who managed to circumvent the safeguards meant to protect investors, such as screening by the crowd, transparency and documentation requirements, independent audit reports, and the withholding of funds until the venture's financial goal has been met. The authors offer some safeguards to help reduce fraudulent behavior in crowdfunding, such as the crowdfunding portals being certified to be legitimate intermediaries or entrepreneurs being certified prior to them being allowed to crowdfund. In a different study, Agrawal et al. (2016) propose the formation of syndicates to reduce the information asymmetry problem. Syndicates can substitute for the due diligence role of venture capitalists (Agrawal et al., 2016).

Lending: Research on crowdlending shows that the design of the campaign is important and must fit the purpose of the fundraising request. In particular, Meyskens and Bird (2015) argue that, when a project rates highly in both social and economic value, then the lending-based model of crowdfunding is most appropriate, since social investors can help an entrepreneur create economic value both directly and indirectly. Also, if the campaign is designed in such a way as to span multiple categories then it is likely to be perceived negatively by potential lenders and this may result in the project being devalued, despite the absence of any shortcomings in quality (Leung and Sharkey, 2014). Moreover, Ly and Mason (2012) show that requests for loans that are perceived as less risky and where the amounts are lower tend to be funded more quickly. In addition, individual borrowers have been shown to attract funding more easily than groups of borrowers (Galak et al., 2011), although the findings of Ly and Mason (2012) that groups of more than six people receive funding more quickly appear to contradict previous results.

By looking at the characteristics of the entrepreneur, Ly and Mason (2012) show that loans to women are funded more quickly. In addition, Lin et al. (2013) find that a borrower's social network of online friendships acts as a signal of credit quality since friendships are associated with a higher probability of successful funding, lower interest rates on funded loans, and lower ex post default rates. The effects are greater when friends have roles and identities that signal better credit quality.

Furthermore, Bruton et al. (2011) connect funding success with borrowers who demonstrate a clear future growth orientation for themselves and their businesses and are skillful at managing 
relationships. In addition, Moss et al. (2014) find that ventures that signal an entrepreneurial orientation with dimensions of autonomy, competitive aggressiveness, and risk taking are more likely to be funded than ventures that signal a virtuous orientation with dimensions of conscientiousness, courage, empathy and warmth. However, on performing content analysis of the narratives posted by entrepreneurs on the Kiva crowdlending website, Allison et al. (2013) find that language conveying confidence, accomplishments or innovativeness is associated with slower funding, not faster. Moreover, in a later paper, Allison et al. (2015) find that language conveying greater profit and risk taking is associated with increases in the time needed to fund a microloan. In addition, the use of language conveying blame and emphasizing the present is associated with faster funding (Allison et al., 2013), and a greater degree of human interest language also decreases the time needed (Allison et al., 2015). Along the same lines, Jenq et al. (2012) find that loans requested by borrowers who appear more needy, honest and creditworthy are funded more quickly.

With respect to successful loan repayment, peer monitoring and group pressure have been shown to reduce delinquency (Al-Azzam et al., 2012). On the other hand, ventures that signal a virtuous orientation with dimensions of conscientiousness, courage, warmth and zeal appear less likely to repay their loans in time or at all (Moss et al., 2014). Regarding the entrepreneur, social ties and religiousness are associated with lower delinquency rates, as is access to a telephone because communication technology is thought to increase group accountability (Al-Azzam et al., 2012).

The crowd's behavior is also of interest in lending-based crowdfunding. Lenders exhibit significant biases in their decisions about which project to fund. Pope and Sydnor (2011) discover biases against listings without a picture and listings with pictures of black people, older individuals, overweight people and people who appear unhappy. At the other extreme, there is discrimination in favor of listings with pictures of women and pictures that show signs of military involvement. Jenq et al. (2012) corroborate these findings by showing how lenders on a crowdlending website seem to favor borrowers who are deemed to be more attractive, who are lighter-skinned, and who are less obese.

Furthermore, lenders are biased toward borrowers who are in social proximity to themselves. Across three dimensions of social distance - namely, gender, occupation, and first name initial lenders tend to give to those who are more similar to themselves (Galak et al., 2011). Evidence further suggests that knowledge acquired through social proximity unearths soft information that mitigates the asymmetry of information reigning over these investment decisions (Morse, 2015). Similarly, Burtch et al. (2014) find that lenders typically prefer borrowers who share a similar culture and are less distant geographically. Cultural distance is associated with lower transaction likelihood, conditional on geographical proximity. The authors interpret this as an awareness effect, suggesting that cultural differences are only relevant insofar as a contributor is aware of them. Along the same lines, Lin and Viswanathan (2014) confirm that lending-based crowdfunding platforms tend to indicate home bias, a tendency for investors to prefer to invest in projects located in the same geographical area, often forgoing better alternatives with a lower risk and higher return if they are located in geographically more distant areas.

Other mechanisms at play include herding behavior. Well-funded borrower listings tend to attract more funding (Zhang and Liu, 2012). However, instead of passively mimicking their peers (irrational herding), lenders engage in active observational learning (rational herding) - they infer the creditworthiness of borrowers by observing peer lending decisions and use publicly observable borrower characteristics to moderate their inferences. At the same time, social network 
effects from friend endorsements weaken the herding effect, as lenders attribute herding to these observable merits.

Rewards. The design of the project is crucial in reward-based crowdfunding. The reward model is appropriate when the project has low social and economic value and so seeks to prove the validity of its concept and gain legitimacy (Meyskens and Bird, 2015). Moreover, lower funding targets and shorter durations signal legitimacy by setting modest, achievable expectations (Frydrych et al., 2014). Also, internal social capital is fundamental to attracting capital and backers in the early stage of a campaign. In turn, these early contributions are closely associated with the likelihood of a project reaching its target capital (Colombo et al., 2015). In this setting, certain combinations of delivery timeliness, product quality, project novelty, sponsor participation, entrepreneur activeness, and sponsor demographics such as age and gender act as sufficient conditions for sponsor satisfaction in crowdfunding (Xu et al., 2016).

In addition, Cumming et al. (2015) show that small, scalable projects are more likely to be funded through the keep-it-all scheme, while large nonscalable projects are more likely to be funded through the all-or-nothing scheme. The usage of all-or-nothing is a clear signal to the crowd that the entrepreneurs commit not to undertake the project if not enough is raised. Therefore, the all-or-nothing model reduces the risk to the crowd, thereby enabling the entrepreneurs to set higher goals, raise more money, and increase the likelihood of reaching their stated goals.

Importantly, crowdfunding investors appear to respond to many of the same signals as venture capitalists - namely, strong founding teams, endorsements from outside the team, and a wellthought-out and researched proposal (Mollick, 2014; Mollick and Robb, 2016). In a study comparing the United States and China, Zheng et al. (2014) find that the entrepreneur's social capital and social network ties have significant effects on crowdfunding performance in both countries. Unlike the traditional venture capital industry, in crowdfunding women have enjoyed higher rates of success compared with men (Marom et al., 2015). To sum up, the factors contributing to successful fundraising include a small and reasonable project goal, public exposure through being featured on the platform, a large number of Facebook friends of the founder, appropriate background and outside endorsements (Mollick and Kuppuswamy, 2014).

Research shows that the size of the project also affects repayment success, with overfunded projects being particularly vulnerable to delay (Mollick, 2014). Project delays have been attributed to a range of problems associated with unexpected success, such as manufacturing problems, the complexity of shipping, changes in scale, changes in scope, and unanticipated certification issues (Mollick, 2014).

Moreover, the crowd is once again shown as succumbing to herding behavior since social information - that is, other crowdfunders' funding decisions - plays a key role in a project's success (Kuppuswamy and Bayus, 2015). In particular, investors are more likely to contribute to a project that has already received a sufficiently large number of backers in a timely manner, which implies that successful funding depends on the ability to reach a critical mass of funding in a given time period (Li and Duan, 2014). This is shown in the typical funding pattern of project support, which is found to be U-shaped. Backers are more likely to contribute to a project in the first and final week compared with the period in the middle of the funding cycle (Kuppuswamy and Bayus, 2015). The explanation for this is that the behavior of other crowdfunders may serve as a project quality signal for others, regarding the type of crowdfunder whose behavior is observed (Lin et al., 2014). This type of herding is called rational herding and it occurs when 
early investments made by expert investors serve as a signal of quality for later investments (Zhang and Liu, 2012). Rational herders are not only concerned about the presence of herding but they decipher the underlying reasons that give rise to the herd and pay attention to whether herding individuals do indeed have better private information than they do.

In a study that examines the role of social capital in crowdfunding from a cross-cultural perspective, Zheng et al. (2014) find that factors such as the entrepreneur's social capital, social network ties, obligations to fund other entrepreneurs, and the shared meaning of the crowdfunding project between the entrepreneur and the sponsors have significant yet differing effects on crowdfunding performance in China and the United States. The authors, therefore, highlight the impact of culture on the success of crowdfunding.

Finally, information privacy is a significant concern of the reward crowdfunding market. Burtch et al. (2015) study the impact of information privacy control mechanisms on investor behavior and find that, when funders are not presented with information controls before paying, they are 5\% more likely to complete a transaction but contribute $\$ 5.81$ less on average compared with funders who are given information controls. On the whole, the net effect is positive, which means that platforms should prefer the post-payment setup of information privacy controls.

In conclusion, so far, we have defined crowdfunding success as a function of funding success, repayment success, the crowd and the market, and unearthed the key factors that contribute to success as documented in the literature to date, organized according to the type of crowdfunding model. For funding success, the common factors across models are the design of the project campaign, and the characteristics of the entrepreneur. Repayment success lags behind in research, and the key factor that appears is the design of the project campaign. With regard to the behavior of the crowd, studies employing sociological and psychological perspectives address factors such as motivations, biases and herding. The market, as segmented by the crowdfunding model, remains the least explored dimension of success. It is worth noting, however, that several papers have explored the issue of market failure for the crowdfunding industry as a whole. We proceed to discuss research gaps and conflicting results as possible avenues for future research.

\section{Avenues for Future Research}

Through the method of a systematic literature review, we are able to paint an elaborate picture of the prominent studies in the crowdfunding literature, and identify specific research questions for scholars interested in this field (Figure 1). To date, the characteristics of the project design and the entrepreneur have taken center stage as signals affecting the likelihood of both funding success and repayment success. The crowd has also enjoyed some of the spotlight as sociological behavior patterns and psychological motivations for funding through this process differ from traditional financing. And, through the discovery of potential market failures, institutional remedies are being proposed. Future researchers have a variety of paths to set out on. 


\section{Figure 1}

Overview of crowdfunding literature

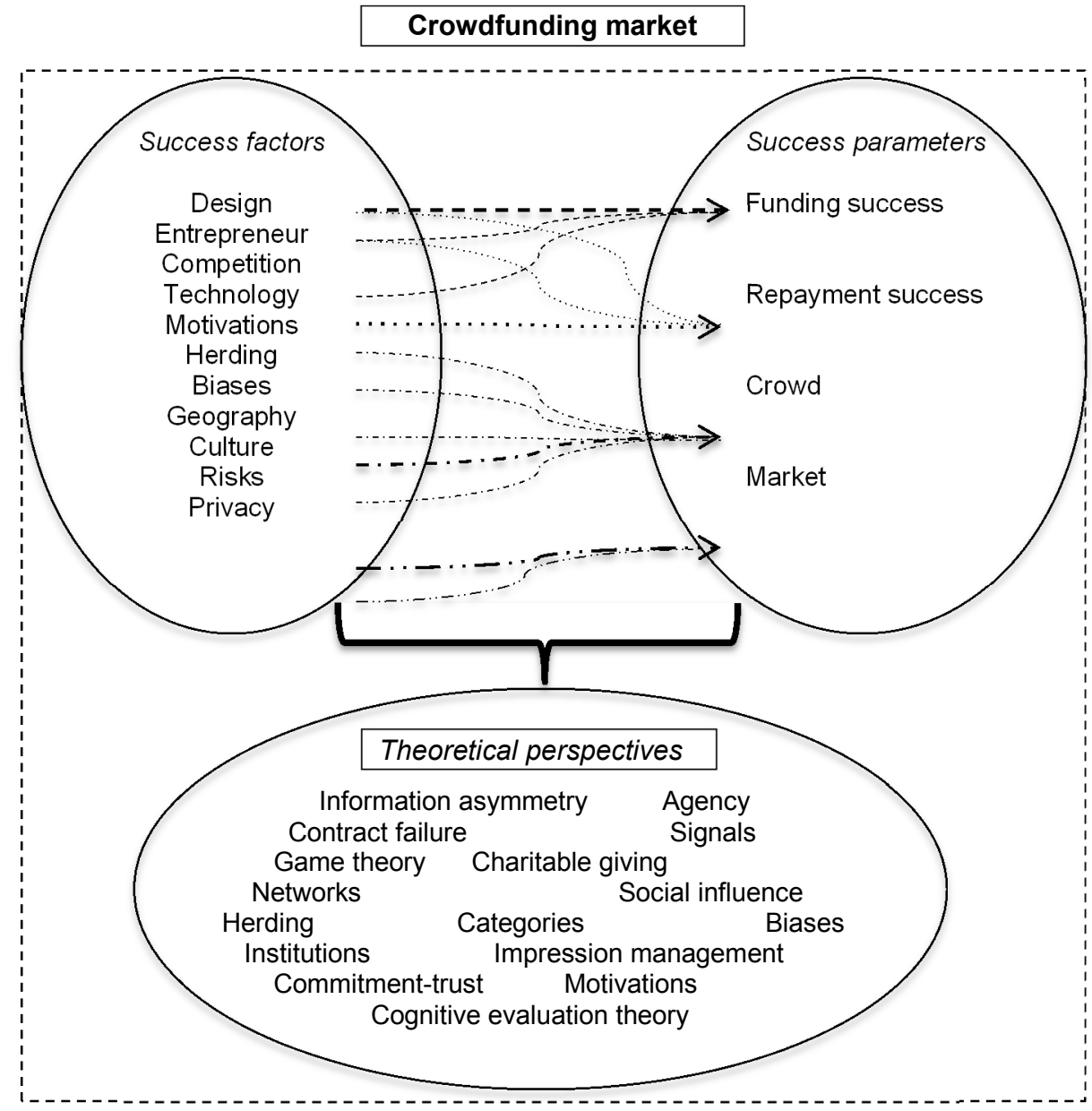

First, it is important to resolve contradictory findings. Specifically, in the context of rewards, some authors find that crowdfunding investors respond to similar signals as venture capitalists, such as strong founding teams, endorsements from outside the team, and a well-thought-out and researched proposal (Mollick, 2014; Mollick and Robb, 2016). On the other hand, Cumming et al. (2015) find that a more complete business plan, schedule, finance plan and design seem to have no effect. Further research is needed to demystify the importance of these characteristics for funding success. Moreover, in the lending context, funding success is positively associated with borrowers who demonstrate a clear future growth orientation for themselves and their businesses and are skillful at managing relationships (Bruton et al., 2011), as well as with ventures that signal an entrepreneurial orientation with dimensions of autonomy, competitive aggressiveness, and risk taking (Moss et al., 2014). However, these results are contradicted by other studies that find that language conveying confidence, accomplishments or innovativeness is associated with slower funding (Allison et al., 2013; Jenq et al., 2012), as is language conveying greater profit and risk taking (Allison et al., 2015). These contradictory findings merit further research, taking into account any special characteristics of the empirical setting. Furthermore, individual borrowers have been shown to attract funding more easily than groups of borrowers (Galak et al., 2011), although the findings of Ly and Mason (2012) that groups of more than six people receive funding more quickly contradict previous results and raise important questions regarding the effect of group design on success and its implications for the different types of crowdfunding models. 
Second, several research gaps have become apparent in this review and we proceed to discuss them within the managerial context in which they arise. In the realm of decision making and biases, work is needed to uncover the biases that hinder the social mission of crowdfunding platforms, and to recommend potential remedies. For instance, home bias has proved to be an obstacle to the spread of crowdfunding practices (Lin and Viswanathan, 2014), and overcoming this would allow access to a geographically wider group of people. To take another example, dealing with the optimism bias displayed by entrepreneurs could help them make more realistic financial demands. As Goldstein and Gigerenzer (2009) and Wright and Goodwin (2009) point out, the biases and limitations of human judgment affect its ability to make sound decisions when optimism influences its forecasts, and this can affect the decisions of both borrowers and lenders. Moreover, there is an opportunity for future research with the aim of understanding individual investors' decision-making processes, by following lenders over time to discern their investing patterns, and determining whether investors fall into discernible longitudinal behavioral pattern groups. The existence of such behavioral influences makes platform design or the choice of architecture (Thaler and Sunstein, 2008) a crucial feature for campaign success. There is ample room for future research to explore how the motivations to invest in different crowdfunding projects depend on the architecture of the platform, and how these motivations are shaped by the institutional and social context in which crowdfunding participants find themselves.

Furthermore, the wisdom of the crowd awaits further evidence. On the one hand, unlike business angels or venture capital funds, crowdfunders might not have any special knowledge about the industry. On the other hand, the "wisdom of the crowd" argument states that a crowd can at times be more efficient than individuals or teams in solving corporate problems. Hence, crowdfunders as a crowd would be more efficient than a few equity investors alone but research is needed to explore this effect further.

In addition, the examination of herding behavior in decision making represents a solid first step in incorporating social and psychological factors into the study of crowdfunding. In the future, scholars can reach out to psychological theories that can set out and explain the impacts of personality traits, moods and emotions on herding behavior. From the perspective of cognitive psychology, cognitive biases may lead to herding on account of cognitive constraints, environmental cues or framing effects (Tversky and Kahneman, 1974). Cognitive factors are moderated by personality and psychological traits and, moreover, the role of affection and emotion cannot be ignored. Some research has already connected the effect of photographs of the fundraiser with the campaign's success, in terms of the key characteristics of gender, perceived attractiveness, physique and skin color (Jenq et al., 2012). However, more information can be gathered from the general content of these photographs, as well as the brightness and colors present down to the pixel level, vis-à-vis any emotions that are evoked in potential investors as they browse through the projects.

The effects of social influence from others' prior funding decisions are of great interest in crowdfunding since the level of financial support and its timing are publicly visible on most platforms. Consequently, it is important to understand what mitigates such herding behavior. One possible factor is geography, as Agrawal et al. (2015) find that local investors - that is, those in geographical proximity - are less liable to herding behavior in an equity setting. Another possibility is the effect of social networks on herding behavior and the conditions under which this mitigation occurs. Research shows how, in lending environments, well-funded borrower listings tend to attract further funding (Zhang and Liu, 2012). However, instead of passively mimicking their peers through irrational herding, lenders engage in active observational learning through rational herding instead. Rational herding entails investors inferring the creditworthiness of borrowers by observing peer lending decisions and using publicly observable borrower 
characteristics to moderate their inferences. As such, the social network effects of friend endorsements weaken the herding effect, as lenders attribute herding to these observable merits. Consequently, the process of interaction between social networks and herding merits further research, as do the factors that determine which effect dominates.

Knowledge on the topic could be made richer by the closer examination of intrinsic and extrinsic motivators beyond the context of donations. Even in equity crowdfunding, further investigation of the financial motivation is needed to ascertain whether there are other incentives. In the end, why invest in equity crowdfunding and not the stock market directly? Allison et al. (2015) shed some light on the relative importance of intrinsic cues for lenders who are intrinsically motivated and self-select to participate in a crowdfunding market. Further research could clarify the motivations of the crowd, in the different types of crowdfunding, and how these compare or contrast with traditional investors.

From a social entrepreneurship perspective, crowdfunding can provide a venture with additional legitimacy, as the selection process by the crowd is perceived to be democratic, and the crowd will thus select the social ideas it deems worthy and necessary. But does crowdfunding really provide legitimacy or is it more frequently perceived as a failure to raise money from venture capitalists? What do professional investors actually think about raising money from the crowd? Moreover, although previous literature treats crowdfunding as a mechanism to raise start-up phase financing, its potential for funding growth and expansion has yet to be examined empirically. The adoption of a longer-term perspective on crowdfunded projects could track performance after funding and yield information on the subsequent stages of the entrepreneurial process.

Economists also have more to discover on the topic. Following the findings of Li and Duan (2014) that achieving critical mass in a timely manner is crucial for successfully raising the target funding, a key business concern then becomes how to attract users prior to reaching critical mass. In general, one way is to rely on extrinsic motivation or ask friends to sign up. A more natural strategy is to build a system that has enough value without network effects. In the case of crowdfunding, where there may be a lot of competition from other projects, these two methods likely correspond to turning to friends and family for early contributions and ensuring that the quality and purpose of the project are good enough and communicated in such a way as to appeal to the widest range of investors possible. Further research could shed light on the strategies that can be employed in the early stages to reach critical mass. Moreover, researchers could start with the more quantitative, albeit idiosyncratic, question of what percentage of the funding target is construed as critical mass - and how this is influenced by a lot of competition from other loans and the investor's profile - for the different crowdfunding models.

Crowdfunding investments have numerous risks, including securities market scandals, business failure, the threat of money laundering, excessive capital allocation to sectors preferred by crowdfunding, subsequent funding failure, investors' lack of liquidity due to the lack of a secondary market and regulatory and compliance risk. Research should be done to achieve a better understanding of the risk factors in the various types of crowdfunding, and propose ways of overcoming them, for each of the players involved. Along these lines, the role of the different intermediaries in the crowdfunding process could be explored to decipher the mechanisms that help mitigate these risks by, for example, building trust.

With respect to methodology, it is important to move crowdfunding research in the direction of qualitative research methods, longitudinal empirical settings, asymmetrical research methods and big data. Qualitative research methods provide a deeper understanding of specific processes, enable 
researchers to see a broader picture of the crowdfunding phenomenon and allow offline activities to be linked with online processes. In addition, it is recommended that future research use panels to model the dynamics of project funding behavior and to control for unobserved project-level heterogeneity. On top of that, asymmetrical approaches may be more powerful in capturing the relationships between the variables of interest. The geographical spread of data sources also provides for greater uniformity as future studies on the topic are published. Last but not least, the use of big data can be leveraged in empirical research to enhance the significance of future findings and bring to light any previously undiscovered correlations or causal relationships.

Finally, there is an overarching need for research to penetrate into all types of crowdfunding models and test the applicability of findings across markets based on donations, rewards, equity and lending. What is more, the cultural differences across continents and countries are worthy of examination in cross-cultural research. Although a subset of alternative finance, crowdfunding itself should be decomposed into the smaller pieces of the puzzle, by business model and geography, as each part behaves differently. The contribution of this review is to encourage scholars to study this phenomenon on its own merits, in greater depth and breadth.

\section{Conclusion}

We systematically reviewed the 82 papers comprising the academic knowledge base on crowdfunding to date. We meticulously defined the concept as an alternative model for project financing, whereby a large and dispersed audience participates through relatively small financial contributions, in a purposeful project, in exchange for physical, financial or social rewards. It is usually done via Internetbased platforms that act as a bridge between the crowd and the projects. Then, we sought to make an eloquent synthesis of the theoretical frameworks applied in these papers and resorted to the three academic domains of economics, sociology and psychology. Next, we explored the empirical papers and categorized their findings in terms of success factors for attracting funding, repaying investors, crowd behavior and the marketplace. Through this method, we were able to paint a picture of the crowdfunding literature to date and identify specific research questions for scholars in this field. Future research directed at the conflicting results brought to light in this study would be of great use to the crowdfunding community. Furthermore, there is ample room for future research aimed at understanding how the motivations to engage in crowdfunding depend on the design characteristics of the project and the founder, and how these motivations are shaped by the institutional and social context in which the founders and crowdfunders find themselves. Looking beyond the current state of the market, we anticipate that practitioner experience, technological developments, regulatory frameworks as well as knowledge building through academic research will play key roles in the advancement of this market in the next few years. Numerous consultancies are offering advice and solutions to crowdfunding platforms and fundraisers, and website designers are enhancing the performance of technology platforms, interactive features and security systems. At the same time, policymakers are slowly stepping in to provide the rules to protect the legitimate interests of people and organizations, as well as guarantee the favorable social impact of crowdfunding, based on accumulated experience and knowledge from the academic end. Importantly, the advancement of knowledge on the topic rests on the future research undertaken by scholars, the contradictions that will be reconciled, the gaps that will be filled, and the bold steps taken toward new empirical and theoretical directions. In the end, as the amount of crowdfunding activity is increasing rapidly, it is up to academics to provide the solid knowledge base for the policymakers to step in. 


\section{References}

Agrawal, A., Catalini, C., \& Goldfarb, A. (2014). Some Simple Economics of Crowdfunding [article]. Innovation Policy and The Economy, 63.

Agrawal, A., Catalini, C., and Goldfarb, A. (2015). "Crowdfunding: Geography, Social Networks, and the Timing of Investment Decisions." Journal of Economics \& Management Strategy, 24(2), 253-274.

Agrawal, A., Catalini, C., and Goldfarb, A. (2016). "Are Syndicates the Killer App of Equity Crowdfunding?” California Management Review, 58(2), 111-124.

Ahlers, G.K.C., Cumming, D., Guenther, C., and Schweizer, D. (2015). "Signaling in Equity Crowdfunding." Entrepreneurship Theory and Practice, 39(4), 955-980.

Akerlof, G.A. (1970). “The Market for 'Lemons': Quality Uncertainty and the Market Mechanism." The Quarterly Journal of Economics, 84(3), 488-500.

Al-Azzam, M., Hill, R.C., and Sarangi, S. (2012). "Repayment Performance in Group Lending: Evidence From Jordan.” Journal of Development Economics, 97(2), 404-414.

Allison, T.H., Davis, B.C., Short, J.C., and Webb, J.W. (2015). "Crowdfunding in a Prosocial Microlending Environment: Examining the Role of Intrinsic Versus Extrinsic Cues." Entrepreneurship Theory and Practice, 39(1), 53-73.

Allison, T.H., McKenny, A.F., and Short, J.C. (2013). "The Effect of Entrepreneurial Rhetoric on Microlending Investment: An Examination of the Warm-Glow Effect." Journal of Business Venturing, 28(6), 690-707.

Andreoni, J. (1990). "Impure Altruism and Donations to Public Goods: A Theory of Warm-Glow Giving.” The Economic Journal, 100(401), 464-477.

Andreoni, J. (2006). "Philanthropy." In Kolm, S.-C. and Ythier, J.M. (eds.), Handbook of the Economics of Giving, Altruism and Reciprocity (vol. 2, pp. 1201-1269). Amsterdam and Oxford: North-Holland.

Ashta, A., Assadi, D., and Marakkath, N. (2015). The Strategic Challenges of a Social Innovation: The Case of Rang De in Crowdfunding." Strategic Change, 24(1), 1-14.

Assenova, V.A., Best, J., Cagney, M., Ellenoff, D., Karas, K., Moon, J., Sherwood, N., Suber, R., and Sorenson, 0. (2016). "The Present and Future of Crowdfunding." California Management Review, 58(2), 125-135.

Baucus, M.S., and Mitteness, C.R. (2016). "Crowdfrauding: Avoiding Ponzi Entrepreneurs When Investing in New Ventures.” Business Horizons, 59(1), 37-50.

Belleflamme, P., Lambert, T., and Schwienbacher, A. (2013). "Individual Crowdfunding Practices." Venture Capital, 15(4), 313-333.

Belleflamme, P., Lambert, T., and Schwienbacher, A. (2014). "Crowdfunding: Tapping the Right Crowd." Journal of Business Venturing, 29(5), 585-609.

Belleflamme, P., Omrani, N., and Peitz, M. (2015). "The Economics of Crowdfunding Platforms." Information Economics and Policy, 33, 11-28. 
Boons, M., Stam, D., and Barkema, H.G. (2015). "Feelings of Pride and Respect as Drivers of Ongoing Member Activity on Crowdsourcing Platforms." Journal of Management Studies, 52(6), 717-741.

Briner, R.B., Denyer, D., and Rousseau, D.M. (2009). "Evidence-Based Management: Concept Cleanup Time?” Academy of Management Perspectives, 23(4), 19-32.

Bruton, G.D., Khavul, S., and Chavez, H. (2011). "Microlending in Emerging Economies: Building a New Line of Inquiry From the Ground Up.” Journal of International Business Studies, 42(5), 718-739.

Bruton, G.D., Khavul, S., Siegel, D.S., and Wright, M. (2015). "New Financial Alternatives in Seeding Entrepreneurship: Microfinance, Crowdfunding, and Peer-to-Peer Innovations." Entrepreneurship Theory and Practice, 39(1), 9-26.

Burtch, G., Ghose, A., and Wattal, S. (2013). "An Empirical Examination of the Antecedents and Consequences of Contribution Patterns in Crowd-Funded Markets." Information Systems Research, 24(3), 499-519.

Burtch, G., Ghose, A., and Wattal, S. (2014). "Cultural Differences and Geography as Determinants of Online Prosocial Lending.” MIS Quarterly, 38(3), 773-794.

Burtch, G., Ghose, A., and Wattal, S. (2015). "The Hidden Cost of Accommodating Crowdfunder Privacy Preferences: A Randomized Field Experiment.” Management Science, 61(5), 949-962.

Cholakova, M., and Clarysse, B. (2015). "Does the Possibility to Make Equity Investments in Crowdfunding Projects Crowd Out Reward-Based Investments?” Entrepreneurship: Theory \& Practice, 39(1), 145-172.

Colgren, D. (2014). “The Rise of Crowdfunding: Social Media, Big Data, Cloud Technologies.” Strategic Finance, 96(4), 56-57.

Colombo, M.G., Franzoni, C., and Rossi-Lamastra, C. (2015). "Internal Social Capital and the Attraction of Early Contributions in Crowdfunding." Entrepreneurship Theory and Practice, 39(1), 75-100.

Connelly, B.P., Certo, S.P., Ireland, R.P., and Reutzel, C.P. (2011). "Signaling Theory: A Review and Assessment." Journal of Management, 37(1), 39-67.

Corazzini, L., Cotton, C., and Valbonesi, P. (2015). "Donor Coordination in Project Funding: Evidence From a Threshold Public Goods Experiment.” Journal of Public Economics, 128, 16-29.

Cumming, D. J., Leboeuf, G., Schwienbacher, A. (2015). Crowdfunding Models: Keep-It-All vs. All-Or-Nothing (May 31, 2015). Available at SSRN: http://ssrn.com/abstract=2447567 or http://dx.doi.org/10.2139/ssrn.2447567

Deci, E.L., and Ryan, R.M. (2000). "The 'What' and 'Why' of Goal Pursuits: Human Needs and the Self-Determination of Behavior.” Psychological Inquiry, 11(4), 227-268.

Deci, E.L., and Ryan, R.M. (2012). "Motivation, Personality, and Development Within Embedded Social Contexts: An Overview of Self-Determination Theory." In R.M. Ryan (Ed.), The Oxford Handbook of Human Motivation (pp. 85-107). Oxford, U.K.: Oxford University Press. 
Dillard, C., Browning, L., Sitkin, D., and Sutcliffe, K. (2000). "Impression Management and the Use of Procedures at the Ritz-Carlton: Moral Standards and Dramaturgical Discipline." Communication Studies, 51(4), 404-414.

Dushnitsky, G., and Marom, D. (2013). “Crown Monogamy.” Business Strategy Review, 24(4), 24-26.

Dushnitsky, G., Guerini, M., Piva, E., and Rossi-Lamastra, C. (2016). "Crowdfunding in Europe: Determinants of Platform Creation Across Countries." California Management Review, 58(2), 44-71.

Ellman, M., and Hurkens, S. (2014). “Optimal Crowdfunding Design.” NET Institute working paper No. 14-21. Available at SSRN: http://ssrn.com/abstract=2507457 or http://dx.doi.org/10.2139/ssrn.2507457.

Frydrych, D., Bock, A.J., Kinder, T., and Koeck, B. (2014). “Exploring Entrepreneurial Legitimacy in Reward-Based Crowdfunding." Venture Capital, 16(3), 247-269.

Galak, J., Small, D., \& Stephen, A. (2011). Microfinance Decision Making: A Field Study of Prosocial Lending. Journal Of Marketing Research, 48S130-S137

Galariotis, E., Villa, C., and Yusupov, N. (2011). "Recent Advances in Lending to the Poor With Asymmetric Information.” Journal of Development Studies, 47(9), 1371-1390.

Gaynor, G., Morse, J.N., and Pevzner, M. (2015). “The Crowdfunding Effect.” Strategic Finance, 97(10), 34-39.

Gerber, E. M., Hui, J. S., \&t Kuo, P. Y. (2012). Crowdfunding: Why people are motivated to post and fund projects on crowdfunding platforms. Working Paper. Retrieved at http://www.juliehui.org/wp-content/uploads/2013/04/CSCW_Crowdfunding_Final.pdf

Gleasure, R. (2015). "Resistance to Crowdfunding Among Entrepreneurs: An Impression Management Perspective.” Journal of Strategic Information Systems, 24(4), 219-233.

Gobble, M.M. (2012). “Everyone Is a Venture Capitalist: The New Age of Crowdfunding.” ResearchTechnology Management, 55(4), 4-7.

Goldstein, D.G., and Gigerenzer, G. (2009). "Fast and Frugal Forecasting." International Journal of Forecasting, 25(4), 760-772.

Gorbatai, A., and Nelson, L. (2015), "Gender and the Language of Crowdfunding." Available at SSRN: http://ssrn.com/abstract=2549354.

Holm, J. (2016). "The \#1 Reason Why Crowdfunding Campaigns Fail". Retrieved from https://www.krowdster.co/blog/the-1-reason-why-crowdfunding-campaigns-fail.html.

Hu, M., Li, X., and Shi, M. (2015). "Product and Pricing Decisions in Crowdfunding." Marketing Science, 34(3), 331-345.

Jones, 0., and Gatrell, C. (2014). "Editorial: The Future of Writing and Reviewing for IJMR.” International Journal of Management Reviews, 16(3), 249-264.

Jenq, C., Pan, J., and Theseira, W. (2012). "What Do Donors Discriminate On? Evidence From Kiva.org." Working paper.

Kahneman, D., and Tversky, A. (1974). "Judgment Under Uncertainty: Heuristics and Biases.” Science, 185(4157), 1124-1131. 
Keynes J.M. (1930). A Treatise on Money. London, United Kingdom: Macmillan.

Kickul, J., and Lyons, T.S. (2015). "Financing Social Enterprises." Entrepreneurship Research Journal, 5(2), 83-85.

Kim, H.-W., and Kankanhalli, A. (2009). "Investigating User Resistance to Information Systems Implementation: A Status Quo Bias Perspective.” MIS Quarterly, 33(3), 567-582.

Kleemann, F., Voß, G.G., and Rieder, K. (2008). “Un(der)paid Innovators: The Commercial Utilization of Consumer Work Through Crowdsourcing.” Translated by S.S. Gissendanner. Science, Technology Et Innovation Studies, 4(1).

Kshetri, N. (2015). "Success of Crowd-Based Online Technology in Fundraising: An Institutional Perspective.” Journal of International Management, 21(2), 100-116.

Kuppuswamy, V., Bayus, B. L. (2015). Crowdfunding Creative Ideas: The Dynamics of Project Backers in Kickstarter. UNC Kenan-Flagler Research Paper No. 2013-15. Available at SSRN: http://ssrn.com/abstract=2234765 or http://dx.doi.org/10.2139/ssrn.2234765

Kuti, M., and Madarász, G. (2014). “Crowdfunding.” Public Finance Quarterly, 59(3), 355-366.

Larralde, B., and Schwienbacher, A. (2012). "Crowdfunding of Small Entrepreneurial Ventures." The Oxford Handbook of Entrepreneurial Finance, edited by D. Cumming. Vol. 369. New York: Oxford University Press.

Lambert, T., and Schwienbacher, A (2010). “An Empirical Analysis of Crowdfunding.” Available at: http://www.crowdsourcing.org/document/an-empirical-analysis-of-crowdfunding-/2458.

Lehner, O.M. (2013). “Crowdfunding Social Ventures: A Model and Research Agenda.” Venture Capital, 15(4), 289-311.

Lehner, O.M. (2014). "The Formation and Interplay of Social Capital in Crowdfunded Social Ventures." Entrepreneurship \&t Regional Development, 26(5), 478-499.

Lehner, O.M., and Nicholls, A. (2014). "Social Finance and Crowdfunding for Social Enterprises: A Public-Private Case Study Providing Legitimacy and Leverage.” Venture Capital, 16(3), 271-286.

Leung, M.D., and Sharkey, A.J. (2014). "Out of Sight, Out of Mind? Evidence of Perceptual Factors in the Multiple-Category Discount.” Organization Science, 25(1), 171-184.

Ley, A., and Weaven, S. (2011). "Exploring Agency Dynamics of Crowdfunding in Start-Up Capital Financing." Academy of Entrepreneurship Journal, 17(1), 85-110.

Li, Z., and Duan, J.A. (2014). "Dynamic Strategies for Successful Online Crowdfunding." NET Institute working paper No. 14-09. Available at SSRN: http://ssrn.com/abstract=2506352 or http://dx.doi.org/10.2139/ssrn.2506352.

Lin, M., Prabhala, N.R., and Viswanathan, S. (2013). "Judging Borrowers by the Company They Keep: Friendship Networks and Information Asymmetry in Online Peer-to-Peer Lending." Management Science, 59(1), 17-35.

Lin, Y., Boh, W.F., and Goh, K.H. (2014): "How Different Are Crowdfunders? Examining Archetypes of Crowdfunders and Their Choice of Projects." Available at SSRN: http://ssrn.com/abstract=2397571 or http:// dx.doi.org/10.2139/ssrn.2397571. Lin, M. - Viswanathan, S. (2014): Home Bias in Online 
Investments: An Empirical Study of Online Crowdfunding Market. Available at SSRN: http://ssrn. com/abstract=2219546.

Ly, P., \& Mason, G. (2012). Individual Preferences Over Development Projects: Evidence from Microlending on Kiva. Voluntas: International Journal of Voluntary and Nonprofit Organizations, (4). 1036

Macht, S.A. (2014). "Reaping Value-Added Benefits From Crowdfunders: What Can We Learn From Relationship Marketing?” Strategic Change, 23(7), 439-460.

Macht, S.A., and Weatherston, J. (2014). "The Benefits of Online Crowdfunding for Fund-Seeking Business Ventures.” Strategic Change, 23(1), 1-14.

Macht, S.A., and Weatherston, J. (2015). "Academic Research on Crowdfunders: What's Been Done and What's to Come?" Strategic Change, 24(2), 191-205.

Marom, D., Robb, A., and Sade, 0. (2015). "Gender Dynamics in Crowdfunding (Kickstarter): Evidence on Entrepreneurs, Investors, Deals and Taste Based Discrimination." Available at SSRN: http://ssrn.com/abstract=2442954.

Massolution, Crowdsourcing.org (2015). 2015 CF Crowdfunding Industry Report. Retrieved at: http://www.crowdsourcing.org/editorial/global-crowdfunding-market-to-reach-344b-in-2015predicts-massolutions-2015cf-industry-report/45376.

Meer, J. (2014). "Effects of the Price of Charitable Giving: Evidence From an Online Crowdfunding Platform.” Journal of Economic Behavior \& Organization, 103, 113-124.

Meyskens, M., and Bird, L. (2015). "Crowdfunding and Value Creation." Entrepreneurship Research Journal, 5(2), 155-166.

Mollick, E. (2014). “The Dynamics of Crowdfunding: An Exploratory Study.” Journal of Business Venturing, 29(1), 1-16.

Mollick, E.R., and Kuppuswamy, V. (2014). "After the Campaign: Outcomes of Crowdfunding.” UNC Kenan-Flagler research paper No. 2376997. Available at SSRN:

http://ssrn.com/abstract=2376997 or http:// dx.doi.org/10.2139/ssrn.2376997.

Mollick, E., and Robb, A. (2016). "Democratizing Innovation and Capital Access: The Role of Crowdfunding." California Management Review, 58(2), 72-87.

Morgan, R.M., and Hunt, S.D. (1994). "The Commitment-Trust Theory of Relationship Marketing.” Journal of Marketing, 58, 20-38.

Morse, A. (2015). "Peer-to-Peer Crowdfunding: Information and the Potential for Disruption in Consumer Lending.” Annual Review of Financial Economics, 7(7), 463-482.

Moss, T.W., Neubaum, D.0., \& Meyskens, M. (2014). The effect of virtuous and entrepreneurial orientations on microfinance lending and repayment: A signaling theory perspective. Entrepreneurship Theory and Practice, 39(1), 27-52.

Mulcahy, D. (2013). “Six Myths About Venture Capitalists.” Harvard Business Review, 91(5), 80.

Nahapiet, J., and Ghoshal, S. (1998). "Social Capital, Intellectual Capital, and the Organizational Advantage.” Academy of Management Review, 23(2), 242-266. 
Ordanini, A. (2009). “Crowd Funding: Customers as Investors.” Wall Street Journal, 23 March, p. r3. Ordanini, A., Miceli, L., Pizzetti, M., and Parasuraman, A. (2011). "Crowd-Funding: Transforming Customers Into Investors Through Innovative Service Platforms." Journal of Service Management, 22(4), 443-470.

Pope, D.G., and Sydnor, J.R. (2011). "What's in a Picture? Evidence of Discrimination From Prosper.com.” The Journal of Human Resources, 46(1), 53-92.

Rivera-Santos, M., Holt, D., Littlewood, D., and Kolk, A. (2015). "Social Entrepreneurship in SubSaharan Africa." Academy of Management Perspectives, 29(1), 72-91.

Rousseau, D., Manning, J., and Denyer, D. (2008). "Evidence in Management and Organizational Science: Assembling the Field's Full Weight of Scientific Knowledge Through Syntheses." Academy of Management Annals, 2475-515.

Ruef, M., and Patterson, K. (2009). "Credit and Classification: The Impact of Industry Boundaries in Nineteenth-Century America.” Administrative Science Quarterly, 54(3), 486-520.

Saxton, G.D., and Wang, L. (2014). "The Social Network Effect: The Determinants of Giving Through Social Media.” Nonprofit and Voluntary Sector Quarterly, 43(5), 850-868.

Schroter, W. (2014). "Crowdfunding Around the World." Forbes. Retrieved at http://www.forbes.com/sites/wilschroter/2014/07/09/crowdfunding-around-theworld/\#254d673b7d09.

Shang, J., and Croson, R. (2009). "A Field Experiment in Charitable Contribution: The Impact of Social Information on the Voluntary Provision of Public Goods." Economic Journal, 119(540), 1422-1439.

Smith, S., Windmeijer, F., and Wright, E. (2015). "Peer Effects in Charitable Giving: Evidence From the (Running) Field.” Economic Journal, 125(585), 1053-1071.

Spence, M. (1973). “Job Market Signaling.” Quarterly Journal of Economics, 87(3), 355-374.

Stemler, A.R. (2013). "The JOBS Act and Crowdfunding: Harnessing the Power-and Money-of the Masses.” Business Horizons, 56(3), 271-275.

Thaler, R.H., and Sunstein, C.R. (2008). Nudge: Improving Decisions About Health, Wealth, and Happiness. New Haven, CT: Yale University Press

Thornton, P., Ocasio, W., and Lounsbury, M. (2012). The Institutional Logics Perspective: A New Approach to Culture, Structure and Process. Oxford University Press.

Thürridl, C., and Kamleitner, B. (2016). "What Goes Around Comes Around? Rewards as Strategic Assets in Crowdfunding." California Management Review, 58(2), 88-110.

Tranfield, D., Denyer, D., and Smart, P. (2003). “Towards a Methodology for Developing EvidenceInformed Management Knowledge by Means of Systematic Review." British Journal of Management, 14, 207-222.

van Staveren, I. (2013). "Caring Finance Practices." Journal of Economic Issues (M.E. Sharpe Inc.), 47(2), 419-426. 
Ward, C., and Ramachandran., V. (2010). "Crowdfunding the Next Hit: Microfunding Online Experience Goods.” Working paper.

Wardrop, R., Zhang, B., Rau, R., and Gray, M. (2015). "Moving Mainstream: The European Alternative Finance Benchmarking Report." University of Cambridge and Ernst and Young, Cambridge.

Wright, G., and Goodwin, P. (2009). "Decision Making and Planning Under Low Levels of Predictability: Enhancing the Scenario Method." International Journal of Forecasting, 25(4), 813-825.

Xu, B., Zheng, H., Xu, Y., and Wang, T. (2016). "Configurational Paths to Sponsor Satisfaction in Crowdfunding.” Journal of Business Research, 69(2), 915-927.

Xu, Y., Enrique Ribeiro-Soriano, D., and Gonzalez-Garcia, J. (2015). “Crowdsourcing, Innovation and Firm Performance." Management Decision, 53(6), 1158-1169.

Younkin, P., and Kashkooli, K. (2016). “What Problems Does Crowdfunding Solve?" California Management Review, 58(2), 20-43.

Zhang, J., and Liu, P. (2012). "Rational Herding in Microloan Markets." Management Science, 58(5), 892-912.

Zheng, H., Li, D., Wu, J., and Xu, Y. (2014). "The Role of Multidimensional Social Capital in Crowdfunding: A Comparative Study in China and US." Information \& Management, 51(4), 488-496.

Zuckerman, E.W. (2000). "Focusing the Corporate Product: Securities Analysts and DeDiversification." Administrative Science Quarterly, 45(3): 591-619. 